NBER WORKING PAPER SERIES

\title{
DO DROPOUTS DROP OUT TOO SOON? \\ INTERNATIONAL EVIDENCE FROM CHANGES IN SCHOOL-LEAVING LAWS
}

\author{
Philip Oreopoulos
}

Working Paper 10155

http://www.nber.org/papers/w10155

\author{
NATIONAL BUREAU OF ECONOMIC RESEARCH \\ 1050 Massachusetts Avenue \\ Cambridge, MA 02138 \\ December 2003
}

I am very grateful to Steve Machin, Josh Angrist, Enrico Moretti, and staff members from the UK Data Archive, for providing me with necessary data for this project. Seminar and conference participants at Berkeley, LSE, the Chicago Federal Reserve, Royal Holloway, Duke, McGill, Queens, NBER Summer Institute, IZA/SOLE Transatlantic Meetings, and the universities of Toronto, British Columbia and Guelph provided helpful discussion. I am especially thankful to George Akerlof, Alan Auerbach, David Autor, Michael Baker, Gregory Besharov, David Card, Liz Cascio, Stacey Chen, Botond Koszegi, John Quigley, Marco Manacorda, Rob McMillan, Justin McCrary, Costas Meghir, Mathew Rabin, Jesse Rothstein, Emmanuel Saez, Aloisious Siow, Alois Stutzer, Jo Van Biesebroeck, Ian Walker, and two anonymous referees for many helpful comments and discussions. I am solely responsible for this paper's contents. The views expressed herein are those of the authors and not necessarily those of the National Bureau of Economic Research

(C)2003 by Philip Oreopoulos. All rights reserved. Short sections of text, not to exceed two paragraphs, may be quoted without explicit permission provided that full credit, including $(\mathcal{C}$ notice, is given to the source. 
Do Dropouts Drop Out Too Soon? International Evidence From

Changes in School-Leaving Laws

Philip Oreopoulos

NBER Working Paper No. 10155

December 2003

JEL No. I20, I21, I28

\begin{abstract}
This paper studies high school dropout behavior by estimating the long-run consequences to leaving school early. I measure these consequences using changes in minimum school leaving ages — often introduced to prevent dropping out - and compare results across the United States, Canada, and the United Kingdom. Students compelled to stay in school experience substantial gains to lifetime wealth, health, and other labor market activities for all three countries, and these results hold up against a wide array of specification checks. I estimate dropping out one year later increases present value income by more than 10 times forgone earnings and more than 2 times the maximum lifetime annual wage. The one-year cost to attending high school would have to be extremely large to offset these gains under a model that views education as an investment. Other, sub-optimal, explanations for why dropouts forgo these benefits are considered.

Philip Oreopoulos

Department of Economics

University of Toronto

150 St. George Street

Toronto, ON M5S 3G7

Canada

and NBER

oreo@economics.utoronto.ca
\end{abstract}




\section{Introduction}

A common approach to explain why some students finish school earlier than others treats education as an investment. Students invest time, forgo earnings, and endure stress to attend school, but only if anticipated gains from doing so are large enough to offset these costs. For high school students, an investment decision involves weighing expected rewards from obtaining a degree to effort required in getting it. Those that dropout drop out because they detest school, lack motivation, or anticipate little reward from graduation [Eckstein and Wolpin, 1999]. But whatever the reason, viewing education as an investment presupposes dropouts choose what's best for them under the circumstances.

While an investment model of school choice considers a dropout decision ex ante optimal, many view such an event as unfortunate. Many policymakers, educators, and researchers (and parents) feel that individual decisions to leave secondary school before graduation lead to sub-optimal lifetime outcomes. This view is no more apparent than from the motivation behind wanting to introduce, maintain, or update compulsory school laws. Such laws have been around for more than a hundred years, and continue to exist in virtually every industrialized country. Motivation for introducing them, or for updating them, often relates to assumptions that children who would have left school earlier are, in fact, better off from staying on. ${ }^{1}$ Viewing education as investment leads to exactly opposite conclusions. In the absence of positive externalities, compulsory schooling restricts choice and should lower welfare among individuals wanting to leave sooner [e.g. Wolf, 2002, Rickenbacker, 1974, Gatto, 2002, Machan, 2000]. ${ }^{2}$

This paper is the first to estimate lifetime opportunity costs from leaving high school using changes in compulsory school laws. Quantifying the overall consequences from dropping out offers

\footnotetext{
1 In North Carolina, for example, the State Superintendent wants to raise the minimum school-leaving age from 16 to 18 , an age, he says, "that better reflects the maturity required to make such an important and life-changing decision" [http://www.ncpublicschools.org/news/01-02/020502.html]. Thomas Upson, a Connecticut Senator expressed similar arguments: "Too many people regret the reckless decisions they made when they were 16 and decided to drop out. Our goal is to try to prevent that" [http://home.comcast.net/ majerus-collins/dropout.htm].

2 While not advocating support for or against compulsory schooling, Chiswick (1969) notes, 'while those compelled to over-invest [in school] experience an increase in their annual post-investment income, they experience a decrease in their marginal and average internal rates of return".
} 
important perspective for evaluating theories of school attainment. Knowing what dropouts give up is essential for understanding why they do it. If rewards to high school are particularly high, such findings could indicate families of school leavers are financially constrained or that the psychological costs from attending are extremely high. But if additional evidence suggested these explanations were unlikely, such findings could also suggest other reasons for leaving school - cultural or peer influences may predominate adolescent decision-making, youths may underestimate the rewards from staying in school or ignore future consequences of their decisions.

Minimum school-leaving laws are ideal instruments for measuring forgone benefits from leaving school because they identify gains for would-be-dropouts without changing incentives or costs. If the instruments are valid, we can estimate counterfactual gains from additional school for students that would otherwise have left sooner. Several previous papers estimate causal effects of education using compulsory school laws as instruments and find strikingly similar results. But none of these papers use their results to discuss implications for explaining dropout outcomes. Angrist and Krueger (1991) use differences in school-entry laws to identify students dropping out with less education because they were born just after the entry cut-off date as opposed to just prior. Students that finished their schooling with a year less of class because of these laws experienced on average 9.2 percent lower adult earnings than those dropping out later. Acemoglu and Angrist (2000) use differences in school-leaving laws across the United States and over time to identify adults made to stay in school for different periods before having the option to drop out. Students compelled to take an extra year experienced an average increase of 10.3 percent in adult earnings. Harmon and Walker (1995), examine the effect on earnings from changes in minimum school-leaving ages in the United Kingdom. They estimate adult earnings rose an average of 15.3 percent for each additional year of school a student had to take.

Other studies examine non-pecuniary outcomes. Lochner and Moretti (2003) find school compulsion lowers the likelihood of committing crime or ending up in jail. And Lleras-Muney (2001) 
uses compulsory attendance laws to examine the effect of education on mortality. She estimates an additional year of education substantially lowers the probability of dying among elderly people.

We cannot begin to discuss these results without first establishing their sensitivity and credibility. It is important to establish that changes in curriculum or economic conditions were not the main reasons underlying subsequent changes in education attainment and outcomes. Several earlier studies assess the effectiveness of compulsory school laws on education attainment, including Schmidt (1995), LlerasMuney (2002), Lochner and Moretti (2003) and Goldin and Katz (2003). Lochner and Moretti and Lleras-Muney examine extensively whether changes in compulsory school laws simply reflect underlying region-specific trends in school attainment. Both conclude school attendance laws raise attainment and not the other way around.

To address these issues further, I demonstrate consistency across countries in finding similar effects of compulsory schooling for the United States, Canada, and the United Kingdom. The crosscountry comparison provides an opportunity to examine estimates under very different circumstances, different institutions, and for different time periods. The large datasets available and the nature of these policies also allow for several robustness analyses. I also show graphically the discontinuity in education attainment and earnings for adults that entered high school just before or just after an increase in the school leaving age.

The main findings suggest one year of compulsory schooling raises subsequent annual earnings by 10 to 14 percent for youths from all three countries (similar to previous studies). I also find large gains to health, chances of employment, and other labor market activities. Using the pecuniary results and predicted wage profiles, I estimate one additional year of high school raises present value earnings by about 2 to 3 times a dropout's maximum lifetime annual wage. These results hold remarkably well against a wide array of specification checks. Whether or not the possibility of non-pecuniary benefits from education are taken into account, the main conclusion of this paper is that the one year cost to attend school would have to be extremely large to offset these gains, under the education investment model. I 
offer alternative explanations that could rationalize compulsory schooling policies. These include temporarily high discount rates, underestimating expected gains, and social pressures that predominate adolescent concerns.

Next section describes the paper's methodology. Section III presents the paper's cross-country data and describes the school leaving laws used for the U.S., Canada, and the U.K. Section IV shows the estimated impact these laws had on overall education attainment and examines the robustness of these findings. Section V presents the main results. Section VI discusses what the results suggest about dropout behavior, and Section VII concludes.

\section{Methodology}

The main regression model analyzes how school leaving laws affect subsequent outcomes earnings in particular. Since changes in these laws vary by region (state, province, Britain/N.Ireland) and time, not at the individual level, all initial data extracts, with individual observations, are first aggregated into cell means. This procedure explicitly removes within region heterogeneity and reduces computation time substantially. When the sample includes both males and females, the data are also categorized into cells by gender. The U.S. sample also groups cells by race.

Define $\bar{y}_{j k l}$ as the average outcome for members among birth cohort $j$, from high school region $k$, and surveyed in year $l$. The equation of interest (weighted by cell group population size) is:

(1) $\quad \bar{y}_{j k l}=\delta \bar{S}_{j k l}+\beta X_{j k l}+e_{j}+e_{k}+e_{l}+e_{j k l}$,

where $\bar{S}_{j k l}$ is the average education attainment for members among birth cohort $j$, from high school region $k$, and surveyed in year $l, X_{j k l}$ includes additional birth cohort, region, and survey year controls, 
$e_{j}, e_{k}$, and $e_{l}$ represent fixed effects for birth cohort, region, and survey year respectively, and $e_{j k l}$ represents the statistical residual. All regressions in the paper compute robust standard error estimates using Huber-White correction methods, clustering by region and birth cohort. In addition to region specific controls for economic and demographic conditions at the time birth cohorts were age 14, $X_{j k l}$ includes quartic age controls for each birth cohort (from different survey years) to estimate age-earnings profiles. Multiple years of cross-sectional data allow for simultaneous age, birth cohort, and survey year effects by assuming two birth cohort effects are the same. Alternative age effects, or dropping the age controls all together does not affect estimates of $\delta$ by very much.

The underlying first stage of the instrumental variable regression is:

$$
\bar{S}_{j k l}=\gamma_{j k}+\alpha X_{j k l}+v_{j}+v_{k}+v_{l}+v_{j k l}
$$

where $\gamma_{j k}$ is the minimum school leaving age faced by birth cohort $j$ from high school region $k, v_{j}$, $v_{k}$, and $v_{l}$ are fixed effects for birth cohort, region, and survey year respectively, and $v_{j k l}$ represents the statistical residual. Equation (2) uses more than time discontinuities to identify the effects from schoolleaving laws. Time trends in the outcome variable are controlled for with birth cohort and region fixed effects. Identifying the effects from school-leaving laws comes from differences in the timing of these laws across regions. The analysis is therefore similar to difference-in-difference estimation, but with more than one intervention and more than one treatment group. The schooling effect, $\delta$, is not identified if unobserved region specific factors that affect the outcome variable also change at the same time school leaving laws change. Several specification checks are carried out to examine this possibility. 


\section{Data ${ }^{3}$}

This section provides an overview of the micro datasets and school leaving laws used in this study. Wherever possible, I tried to maintain consistency in sample selection, school laws, and variable definitions across all three countries. The main analysis focuses on all 25 to 64 year old males and females who were aged 14 in the years that the school leaving ages were available.

\section{A. The United States}

Most of the U.S. analysis uses an extract of native-born individuals aged 25 to 64 from the six decennial Census microdata samples between 1950 and 2000. ${ }^{4}$ All Censuses contained individual wages, poverty status and labor force participation, but only the 1990 and 2000 datasets contained disability outcome measures. The initial sample size among those with positive wages was 2,814,203. After collapsing into cell means, there were 29,804 cells by state, birth cohort, census year, and gender, and 15,003 cells among males. Hawaii and Alaskan born respondents were excluded.

I coded the schooling variable for individuals in the 1950 to 1980 data as highest grade completed, capped at 17 to impose a uniform topcode across censuses. Following Acemoglu and Angrist (2000), average years of schooling were assigned to categorical values in the 1990 and 2000 Censuses using the imputation for males and females in Park (1994). The earnings variable, log weekly wage, was calculated by dividing annual wage and salary income by weeks worked, and taking logs.

\footnotetext{
${ }^{3}$ The STATA codes for generating the U.S. extracts and results are available on my web site. The U.S. Censuses are available through the Minnesota Population Center [http://www.ipums.umn.edu/usa/]. The U.K. data are available through UK Data Archive [http://www.data-archive.ac.uk/]. The Canadian Census data used for this paper are not available outside Statistics Canada. However, while the precision was smaller, I found little difference in the results when working with the Public Use Microdata files. These data are available through Statistics Canada [http://www.statcan.ca].

4 The specific datasets used were the 1950 General $1 / 330$ sample (limited to those with long-form responses), the 1960 General 1 percent sample, the 1970 Form 2 State 1 percent sample, the 1980 Metro 1 percent sample, the 1990 1 percent unweighted sample, and the 20001 percent unweighted random sample.
} 
The cell groups were assigned a minimum school leaving age according to the year a birth cohort was 14 years old and the state they were born. ${ }^{5}$ Figure 1 shows the school leaving ages, enacted between 1915 and 1975, used for the U.S. analysis. I measured each school leaving age as the minimum between a state's legislated dropout age and the minimum age required to obtain a working permit. ${ }^{6}$ A few states during this period had no laws in place. I grouped the 2.2 percent of the sample that faced school-leaving ages less than 14 into one category (school leaving age $<14$ ). All others faced dropout ages of 14, 15, or 16. The laws changed frequently over this period, both across states and within states over time. About one-third of the variation in the school leaving age is across-states and two-thirds from within. Not all changes were positive.

I also generated control variables for state economic and demographic conditions in the year the laws were in place. For each Census between 1910 and 1980, I calculated the fraction of the population in each state living in an urban city, the fraction living on a farm, black, in the labor force, in the manufacturing industry, and average age. Values between decades were generated by linear interpolation.

\section{B. Canada}

The data extract for Canada comes from the 33 percent sample of the 1971 Census, and the five 20 percent samples of the 1981 to 2001 censuses. $^{7}$ The main extract contained 25 to 64 year olds, born in a Canadian province, who were 14 years old between 1925 and 1975 . While provincially legislated school leaving ages were available for a wider range of years, I chose this span because the cohorts aged

5 The analysis assumes that Americans went to school in their state of birth, Canadians went to school in their province of birth, British born residents went to school in Britain, and Northern Irish residents went to school in Norethen Ireland. Some individuals will be mismatched. If mobility across regions is unrelated with law changes, this measurement error will not bias our estimates. Lleras-Muney (2001) concludes this seems to be the case for the U.S.

6 Acemoglu and Angrist (2000), Lleras-Muney (2001) and Goldin and Katz (2003) find working permit restrictions were often more binding than school leaving age restrictions. The results are not sensitive to using just the dropout age as the compulsory school law variable, or the predicted mandatory number of school years, used by Acemoglu and Angrist and Lochner and Moretti (2003).

${ }^{7}$ The 1976 Census excludes earnings information and was omitted. 
14 before 1925 were older than 55 in the 1971 census, and compulsory school laws were often minimally enforced at the beginning of the century. The initial sample size among those with positive wages was enormous: 8,208,030. After collapsing into province, birth cohort, gender, and census groups, the cell sample size was 4,120 among males and females, and 2,060 among males.

The education variable used for the Canadian analysis was highest grade attained in a primary or secondary school. This measure was asked in addition to highest degree completed. An individual could report attaining less than 12 years of high school while still graduating from college or university. A complication with this measure arises because some provinces offered a senior matriculation year with Grade 13 and some provinces allowed graduation in high school after Grade 11. I therefore top-coded the grade attainment measure to 11 . This recoding did not affect the ability to identify would-be-dropouts compelled to take additional schooling. Dropouts that entered school at age 6 and advanced a grade every year were still able to leave school before Grade $12 .{ }^{8}$ I used the log of annual wages and salaries as the earnings variable for the Canadian data. I did not convert this variable to weekly earnings because a considerable number of full time workers excluded their paid vacations or sick leave when reporting number of weeks last year worked, contrary to Census instructions.

Figure 2 displays the minimum school leaving ages legislated by province, between 1925 and 1975. These laws were compiled directly from provincial Statues and Revised Statutes containing the Acts of legislation and amendments since inception. In a previous study, I documented the history of these changes and other compulsory school laws extensively [Oreopoulos, 2003b]. A few provinces in the first half of the century legislated different dropout ages depending on whether youths attended schools in urban or rural areas. For these cases I recorded the dropout age as that for rural areas, since most often that period, the majority of residents lived in rural areas. All provinces except British Columbia experienced legislated increases. Working permit exceptions below the school leaving age

\footnotetext{
8 See Oreopoulos (2003b) for alternative assumptions to this variable, and alternative choices for the education attainment variable. In general I find, while this topcoding generates the most precise estimates, alternative coding does not change the main findings.
} 
were rarely applied. Less than 12 percent of the sample faced a school leaving age of 16 . I chose to group individuals facing a school leaving age of either 15 or 16, since the effect on grade attainment from raising the school leaving age to 16 from 15 was not significantly different from zero but was imprecisely measured. Including an indicator for facing a school leaving age equal to 16 did not alter the second stage estimates.

Similar to the U.S. extract, I also generated control variables for provincial economic and demographic conditions using historical Census tabulations and linear interpolation. I calculated control variables for the fraction of the population in each province in urban areas, in the manufacturing sector, female, and the average age.

C. The United Kingdom

The U.K. analysis combines 15 U.K. General Household Surveys (GHHS), from 1983 to 1998 (the 1997 GHS was cancelled), to 14 Northern Ireland Continuous Household Surveys, from 1985 to 1998. I refer to both as General Household Surveys, since both questionnaires were almost identical. The major difference was that earnings from the UK GHHS were coded exactly, while earnings from the Northern Ireland GHSS were coded by category. Average earnings were assigned for Northern Irish individuals within grouped earnings categories. An advantage of the UK data is that education is recorded as the age an individual completed full time education. This measure corresponds exactly with the school leaving age laws. The U.S. and Canadian measures of education record grade attained or completed, and miss the full effect of compulsory schooling when high school students remain longer in school from these laws, but do not advance a grade. The combined dataset contains 65,098 individuals aged 32 to 64, who were 14 between 1935 and 1965 (the data only go back to 1983, so we cannot use respondents younger than 32 for this analysis). The data include British born adults and all extracted respondents from the Northern Ireland surveys because foreign-born were not identified. The data were 
aggregated into cell groups by survey year, gender, birth cohort, and region (Britain or Ireland). The remaining number of cells was 1,492 , and half this for males.

There were only 2 changes to the school leaving age in Britain and Northern Ireland between 1935 and 1965, but they were both remarkably effective and influential. Legislation from Great Britain's 1944 Education Act led the school leaving age in England, Scotland, and Wales to rise in 1947 from 14 to 15 years. ${ }^{9}$ Figure 3 A displays the effect this legislative change had on early school-leavers. Before 1947 , a very high fraction of children left full-time school at age 14 (or less). Over just three years however between 1945 and 1948 - the portion of 14 year-olds leaving schools falls from about 57 percent to less than 10 percent. $^{10}$ The ability to accommodate the massive rise in enrolment was possible through a concerted, almost military-like, national operation that expanded the supply of teachers, buildings, and furniture within the three-year span. The 1947 change seems to have little effect on the fraction of children dropping out at age 15 or less - it appears virtually everyone that would have left school at age 14 , left at age 15 after the change. ${ }^{11}$

The 1947 Education Act in Northern Ireland was closely modeled on the British one. The rise in the school-leaving age, from 14 to 15 , however, was not implemented until 1957 due to political stonewalling. Figure $3 \mathrm{~B}$ charts the proportion of youths aged 14 dropping out, and the proportion

\footnotetext{
${ }^{9}$ For a more detailed analysis of the history of British education and the 1944 Education Act in particular, see Halsey, Heath and Ridge (1980). The authors argue, "the 1944 Act put a legislative stamp on forty years of progress towards separate, competitive, and free secondary education for all". Although other reforms were included in the Act, the changing of the school-leaving age in 1947 had, by far, the most sudden and influential impact on students.

${ }^{10}$ The finding that some adults reported finishing school at age 14, even after the school-leaving age had changed, likely reflects measurement error, noncompliance, or delayed enforcement.

${ }^{11}$ The term 'dropout' is something of a misnomer in the UK, since the those that failed to advance to secondary school were expected to leave at the earliest opportunity. For those wanting to advance in school beyond age 14 prior to 1947 , the process typically involved moving from elementary to secondary school at age 12 . Elementary schools offered education past age 11, but usually students that stayed did so until reaching age 14. Pupils transferred to secondary school at age 11, at no cost, on the basis of competitive examinations. The proportion of free places began in 1907 at 25 percent of total attendance, and rose to more than 50 percent by 1931 . The other half entered by paying fees that were subsidized more than two-thirds by the state. The 1944 Education Act removed these fees, in addition to making the first year of secondary school compulsory. For a discussion of the history of British and Irish education over the period of analysis, see Halsey at al. [1980], Barnard [1961], Dent [1954, 1957, 1970, 1971], Gosden [1969] and Durcan [1972]. I shall occasionally refer to UK school leavers as dropouts for convenience.
} 
dropping out at 15 or less. A clear break occurs for the portion of early school-leavers in 1957 . The influence on school attainment from the change in the school-leaving age is clearly visible. ${ }^{12}$

\section{The Effect of School-Leaving Laws on School Attainment}

Table 1 presents the first-stage effects of the school leaving age changes on education attainment, specified as in equation (2), and the corresponding reduced form effects of the school leaving age on earnings. The estimates for the U.S. are listed first. Recall that the data are initially aggregated into cell means and weighted by population size. All regressions include fixed effects for birth year, region, survey year, gender, race, and a quartic in age, and additional regional demographic and economic controls according to when cohorts were aged 14.

Column 1 shows a monotonic relationship in the effect from raising the school leaving age on the total number of years of completed schooling. For the full sample, years of schooling is .24 years higher for those that faced a dropout age of 14 compared to those that faced a smaller dropout age, or none at all. Average school attainment increases by .023 years from raising the dropout age to 15 , and another .20 years from raising it to 16 (no state in the period examined enforced a dropout age higher than 16). We can easily reject that the coefficients on the laws are zero, with an F-statistic of $87.8 .^{13}$ Column 2 shows similar estimated effects if we restrict the sample to only those with less than 12 years of completed schooling (and then collapse the data into cell means). Focussing on this sample zeros in on the individuals most likely to be affected by the dropout age changes. The estimated effects from facing

\footnotetext{
${ }^{12}$ An earlier version of this paper [Oreopoulos, 2003a] includes the change in the school leaving age from 15 to 16 in 1973 for both Britain and Northern Ireland. Since the change occurred at the same time for both Britain and Northern Ireland, this paper's methodology cannot identify the impact from the change. The previous analysis included data from the Republic of Ireland, whose minimum school leaving age changed once, from 14 to 15 in 1972. The Eurobarometer surveys contain data for these three regions, and categorical family household income data. Using these surveys, I estimate returns to compulsory schooling using the 5 school leaving age changes and find similar results compared to those presented here.

${ }^{13}$ The $\mathrm{R}^{2}$ for this regression that uses population weighted cell means is .9258 , and .9242 if we leave out the dropout age indicators.
} 
different dropout ages when young are about the same, as we would expect if those compelled to take additional schooling from changes in these laws still dropped out, but dropped out later. ${ }^{14}$

Compulsory school laws affect those intending to leave high school at early grades. If changes to these laws do not cause students to attain post-secondary schooling, the estimated effects of facing different dropout ages among those with at least some post-secondary schooling should be zero. ${ }^{15}$ If other state specific policies or economic conditions improved at the same time dropout ages increased, we might expect the dropout age changes to correlate with education attainment among the post-secondary school sample. Column 3 shows this is not the case. For the sample with more than 12 years of schooling, none of the dropout ages are related to their education attainment.

The last three columns show the reduced form estimates for the effects of these dropout ages on log weekly earnings. The main purpose of showing these results is to demonstrate that changes in the dropout ages do not affect earnings among the post-secondary sample. Just as we should not expect these laws to impact post secondary schooling attainment, we should not expect these laws to affect outcome variables for the higher educated sample. If we did observe this, we might concern that other factors that affected both dropouts and graduates underlie the correlations in Table 1. While the laws are strongly related to earnings among dropouts, Column 6 shows no noticeable relationship between dropout ages faced when young and earnings for the post-secondary school sample. I also interpret these results as suggesting no state-specific externalities from raising high school education attainment on the same birth cohorts that attained post secondary school.

Table 1 also presents parallel results for Canada. The results are similar to those from the U.S extract. High school grade attainment is .41 grades higher, on average, for those that faced a dropout age

\footnotetext{
${ }^{14}$ The results also suggest changes in U.S. school-leaving laws influenced would-be dropouts to graduate. If we restrict the initial sample to those with 12 or less years of completed schooling, the findings are very similar to those from using the full-sample.

${ }^{15}$ Lang and Kropp (1986) suggest that individuals intending to complete one or two additional years of schooling after the minimum age required may obtain additional education after the dropout age is changed to avoid signalling to employers they are in the same category as those who leave school at soon as possible. If this influence caused a significant number to obtain post-secondary schooling, we might expect the coefficients to be positive.
} 
of 14 , compared to those that faced a lower age limit. Grade attainment is .23 years higher on top of that, for the group of Canadian youths that faced a dropout age of 15 or 16 . Again, we easily reject the coefficients on the school leaving law indicators are zero. Column 2 shows very similar point estimates for the dropout age effects after restricting the same to only those that attained less than 12th Grade. Virtually everyone in the sample that attained some post secondary schooling reported attaining Grade 11 or more. To examine whether dropout age changes in Canada affected higher levels of education, I used a different school attainment variable since the one used in the first two columns, grade attained, only goes up to great 12. The dependent variable in column 3 for the Canadian data is an indicator for post secondary schooling. Similar to the U.S. results, I find no evidence that changes in dropout ages in Canada affected post secondary education attainment among the sample that completed Grade 11 or more. The reduced form results from the Canadian extract in columns 4 to 6 also show no effect from dropout age changes on annual wages among the higher educated sample.

The increase in the minimum school leaving age from 14 to 15 in Britain and in Northern Ireland has the largest estimated effect on education attainment. This is not surprising, considering the striking discontinuities in figures $3 \mathrm{~A}$ and $3 \mathrm{~B}$. Raising the school leaving age from 14 to 15 increased the average age students left full-time school by more than half a year for the sample that left when less than 17 years old. The F-statistic for rejecting that the coefficient for the higher dropout age is zero is 358.5 , for the early school leaver sample. I find no significant evidence that the higher school leaving age affected those that left school at age 18 or more. Raising the school leaving age to 15 increased annual wages overall by about 5.1 percent among early high school leavers, but had no discernable impact on wages for more educated workers.

To further address the concern that region-specific trends underlie the dropout age and education relationship, I present evidence that future dropout age changes do not correlate with current dropout decisions. In Table 2, I follow Lleras-Muney (2002) in matching individuals to future school leaving ages, based on their region of birth and year when aged 14. Columns 1 and 2 show the results from 
regressing education attainment on a birth cohort's own dropout age faced at age 14, and the dropout age that later birth cohorts one or two years after. Each row of these two columns shows results from separate regressions. ${ }^{16}$ The same state/cohort/time fixed effects and controls used for last table's analysis are included here.

For Canada and the U.S., the current school leaving age significantly affects education attainment, while future school leaving ages have small or no effects. For the U.K., an immediate future change to the dropout age is negatively related with school attainment. Those in high school in Britain just before the 1947 increase in the school leaving age and those in Northern Ireland just before the 1957 change were more likely to leave school early relative to other birth cohorts. I have little explanation for this finding, but the negative relationship is opposite to what we would have expected if other factors around the time of the law change affected education attainment. The finding only reinforces the U.K. results. $^{17}$

We can carry out the same validity tests using earnings as the outcome variable instead of education attainment. We should not expect future dropout age changes to affect earlier dropouts' earnings, except if raising overall education attainment leads to positive externalities for everyone. Columns 3 and 4 of Table 2 show the regressions of log earnings on current and future dropout ages, plus the usual fixed effects and regional controls. In every case, the reduced for effects of a cohorts' own dropout age affects their earnings. We also observe zero or small effects on earnings from future dropout ages. Such findings indicate no evidence that the first-stage or reduced-form results are chiefly driven by other immediate factors.

Another way to control for conditions surrounding the law changes is to include upcoming dropout ages as control variables themselves. The first row in column 5 shows the U.S. return to

\footnotetext{
${ }^{16}$ These regressions use a single variable for the dropout age instead of the indicator variables used for Table 1 and for the main results in Section V. Cohorts that faced a dropout age less than 14 were assigned a value of 13 for both the U.S. and Canadian samples.

${ }^{17}$ The coefficients become insignificant and close to zero when using a wider sample of birth cohorts, aged 14 between 1935 and 1985 instead of the sample between 1935 and 1965.
} 
compulsory schooling estimate from regressing log weekly earnings on schooling, fixed effects for year of birth, state, Census year, gender, race, a quartic in age, and control variables for fraction of state living in urban areas, fraction black, in the labor force, in the manufacturing sector, female, and average age based on when a birth cohort was aged 14. Schooling is instrumented by a single variable for a cohort's own dropout age. I estimate an additional year of compulsory schooling raises earnings by about 15.1 percent. Rows 2 and 3 show how this estimate changes when adding controls for upcoming dropout changes. The point estimate falls slightly with the inclusion of this control, but not by any significant amount. The inclusion of upcoming dropout age changes while facing a dropout decision also has little effect on overall estimates of compulsory schooling for Canada and the U.K.

Figure 3 demonstrates graphically the discontinuity in average education attainment and earnings at the time of a law change. Each panel shows estimates of coefficients on lead and lag indicators for whether compulsory schooling increases. I selected the high school dropout samples for each country and aggregated the data by region and birth cohort groups. The dependent variables are schooling and log earnings. Lags include years -12 to -3 . Leads include years +3 to +12 . The regression also includes region and birth cohort controls fixed effects.

Figure 3 shows clearly identification of the effects of compulsory school laws comes from changes to education attainment and earnings immediately or soon after school leaving age changes and not before. In Panel A, average years of completed schooling and average log weekly earnings among U.S. cohorts show no noticeable trend leading up to the dropout age increase. Between cohorts 3 years before and 3 years after an increase, average years of completed schooling rises .150 years. Log weekly earnings rises over the same period by .025 points. If we divide the earnings increase by the schoolings increase, we arrive at a return to compulsory schooling estimate of 16.7 percent, which is not much higher than the full-sample estimates displayed below.

Earnings increases appear to occur more gradually for birth cohorts exposed to more restrictive compulsory school laws. Such results could indicate adjustment costs for cohorts compelled to stay in 
school immediately after a change, or that legislated changes took some time to become fully enforced. Even as education attainment subsequently rises after a law change, earnings also subsequently rises. The graphs show earnings and education moving roughly in tandem immediately following a law increase, and after controlling for region and year of birth. The figures are important because they suggest that dropout age increases raise education attainment and subsequent earnings, and not that they simply respond to underlying trends in schooling.

To summarize, the findings indicate no evidence that the first-stage and reduced-form results are chiefly driven by factors other than a causal effect from compulsory schooling. For all three countries, I estimate strong effects on education attainment from raising the minimum school leaving age on a sample of high school dropouts, and virtually no effect on a sample with post secondary schooling. I find little influence that changes in dropout ages to later birth cohorts impacted education attainment for earlier cohorts. Plotting education attainment and earnings by cohorts exposed to more or less restrictive school laws shows a clear discontinuity in attainment at the time laws increased.

\title{
V. The Effect of Compulsory Schooling on Adult Outcomes
}

\author{
A. Earnings
}

Instrumental variable estimates of equation (1) with log earnings as the outcome variable are shown in Table 3. All regressions include fixed effects for birth cohort, region, survey year, gender, and a quartic in age. The U.S. results also include a dummy variable for race and state controls for fraction of state living in urban areas, fraction black, in the labor force, in the manufacturing sector, female, and average age based on when a birth cohort was age 14. Similar province controls for Canada include fraction in urban areas, fraction in the manufacturing sector, female, and average age. Data are grouped into means by birth year, region, gender, race (for the U.S.) and survey year. Huber-White standard 
errors are shown from clustering by region and birth cohort. Column 2 shows these estimates for the full country samples. Column 3 shows the results using only individuals with less than post-secondary schooling. Column 1 shows corresponding least squares (OLS) estimates using data grouped into means by education attainment, birth year, region, gender, race, and survey year.

I estimate that dropouts compelled to take an additional year of high school earn about 10 to 14 percent more than dropouts without the additional year. The returns to compulsory schooling estimates are remarkably consistent across all countries, whether restricting the initial sample by gender or race (for the U.S.). The estimates from the smaller sample of high school dropouts vary little from the full sample, as we would expect if compulsory school laws have minimum impact on enrolment beyond high school and on outcomes of those with post secondary schooling. The U.S. and Canadian results are measured precisely, with standard errors between .01 and .02 , while the U.K. results have wider confidence regions around similar point estimates (ranging from .073 to .158). The IV estimates try to identify gains from schooling among dropouts wanting to leave earlier, whereas the OLS estimates include possibly heterogeneous gains from schooling at different levels and among individuals with different family background and circumstances. ${ }^{18}$ I restricted the OLS estimates to the high school sample in order to narrow the heterogeneity among groups identified in the OLS and IV results. The OLS estimates of the gains to schooling are similar for the Canadian and U.K. samples, but lower for the U.S. sample - a common finding from previous studies using compulsory school law instruments. I view these results to suggest the marginal gains from schooling among individuals wanting to leave school as soon as possible may be higher relative to the marginal gains for other early school leavers.

\section{B. Health, Employment, and Poverty}

\footnotetext{
${ }^{18}$ Angrist, Imbens and Rubin (1996) (and others) point out an instrumental variables approach identifies only the average treatment effect for the group impacted by the instrument.
} 
The results in Table 4 show other effects from compulsory schooling. Health outcomes are strongly associated from the minimum school-leaving age changes, corroborating with Lleras-Muney's (2002) finding that schooling lowers mortality. The 1990 and 2000 U.S. Censuses ask questions about physical and mental health limitations. Among all individuals in the sample aged 25 to $74,9.2$ percent claim a physical or mental health disability that limits personal care. I estimate an additional year of compulsory schooling lowers the likelihood of reporting such disability by 1.7 percentage points, similar to the OLS estimate. A year of compulsory schooling also lowers the likelihood of reporting a disability that limits daily activity by 2.5 percentage points. For the U.K., the GHHS questionnaire asks respondents to self report whether they are in good, fair, or poor health. A one-year increase in schooling lowers the probability of reporting being in poor health by 3.2 percentage points, and raises the chances of reporting being in good health by 6.0 percentage points.

Schooling also affects many labor market outcomes in addition to earnings. In all three countries, I find compulsory schooling lowers the likelihood of respondents being in the labor force and looking for work. The magnitude of the effect is similar across countries, and similar compared to corresponding OLS estimates. Compulsory schooling also lowers the likelihood of receiving welfare and being classified as poor. Dropouts that drop out one year later are 6 percentage points less likely to fall below the U.S. Poverty Line and 3 percentage points less likely to fall below Canada's Low-Income-Cut-Off. ${ }^{19}$

\section{Present Value Gains From Dropping Out One Year Later}

To predict present value financial gains from an extra year of compulsory high school, I reestimate equation (1) using the samples of male dropouts for each country and include respondents aged 15 to 64 to help predict the shape of a dropout's wage profile over his entire working period. Figure 5

\footnotetext{
${ }^{19}$ A household falls below the Low Income Cut-off if they spend more than 20 percentage points above the average comparative household on food, clothing, and shelter.
} 
shows projected earnings of 15 and 16 year old dropouts for each country using quartic age coefficients, returns to compulsory schooling estimates, and a baseline wage of $\$ 7,525$ for 15 year old dropouts at age 15 (the average wage among 17 year old male dropouts working 50 hours or more in the 2000 U.S. Census). ${ }^{20}$ It makes no difference what starting wage we choose as the base for calculating the annual values, as long as we compare present value gains relative to the wage profiles used to calculate them (e.g. the maximum or initial wage).

The profiles take the usual shape, rising initially with age, levelling off around 40, and falling at late ages. They exclude initial earnings year for 15 year-old dropouts. I consider this amount later when discussing foregone earnings. For the U.S., a male dropout that left school at age 16 earns 15.4 percent more, each year, on average, compared to a dropout that left school at age 15 . The corresponding gains for male dropouts in Canada and the U.K. are 12.9 percent and 13.7 percent respectively. Note that the shape of the profiles does not depend crucially on the underlying initial choice of country, earnings measure, starting age, or education attainment sample (everyone or everyone with less than high school). The shape also does not depend on assuming a constant returns to compulsory schooling over the profile.

Table 5 converts the annual earnings differences for each country to present value (to age 15), using discount rates of 3,5, and 7 percent. The appropriate rate, discussed more below, depends on relative risk assumptions. If dropping out a year later increases expected earnings but also increases the probability of ending up with particularly low wages, we may want to consider higher discount factors above the risk-free rate. If dropping out later improves the chances of always doing no worse than before

\footnotetext{
${ }^{20}$ In order to estimate wage profiles for earlier ages in the U.K., I widen the sample to those 14 between 1935 and 1985, and include an indicator for whether a cohort faced a dropout age of 16 after the change in Britain and Northern Ireland in 1973. To identify the effects of this change, I drop the birth cohort fixed effects from the instrumental variable regression and include only a quartic in age, a Northern Ireland indicator, and fixed effects for survey year. Many multiple survey years help reduce average birth cohort trend effects, but cannot remove them with certainty as with the other previous regressions. Finding similar results, however, shows the U.K. results are not determined by diverging earnings and education trends in Britain and Northern Ireland. Harmon and Walker (1995) use this approach to estimates returns to compulsory schooling in Britain. Results are similar working only with the more accurate British earnings data.
} 
(so that the wage distribution for 16 year-old dropouts stochastically dominates the distribution for 15 year-old dropouts), the appropriate rate to use for discounting is, at most, the risk-free rate. With an annual log earnings gain of .154 for the U.S. projections, Column 1 shows the average present value gain from dropping out a year letter is $\$ 103,593$ under a 3 percent discount rate. That amount exceeds foregone earnings by a factor of 13.8 and peak annual lifetime wages by a factor of 3.0. If foregone earnings were the only costs incurred while attending school, the implicit rate of return from the additional year would be 29.5 percent.

The comparisons do not change much with alternative discount rates or annual rates of return from compulsory schooling. Even with a 7 percent discount rate, the PV gain in Column 1 exceeds forgone earnings by 6.4 and peak annual wages by 1.4. Supposing that the individual annual earnings gains are lower, at 7 percent, PV earnings are still 4.0 times foregone earnings and almost the same as one year of peak annual wages under a 5 percent discount rate. Results for Canada and the U.K. are very similar.

\section{Interpretation}

\section{A. Compulsory School Laws Should Go}

One way to frame the discussion in interpreting the above results is whether compulsory school laws should exist at all. Treating education as an investment, students, whether financially constrained or not, forego earnings and endure possible psychological costs to attend school if the expected overall future gains from doing so are large enough to offset these costs. If not, the optimal choice is to leave. Compulsory schooling prevents that option. If students already choose optimally when to leave, then imposing a longer stay in school makes them worse off, on average, than before. 
The results from last section suggest the average gains from schooling, among would-be dropouts, are very large. Some of these gains may be attributable from positive externalities generated from increasing a regions' enrolment and we should not include these gains when considering an individual's dropout decision. But Table 2 finds increases to school leaving ages for cohorts born a few years later did not lead to significant differences in the gains estimated for earlier cohorts. Even if we allow one-third or more of the financial gains to compulsory schooling to come from externalities, Table 5 shows the remaining amount still substantially exceeds forgone earnings. Accounting for possible nonpecuniary benefits from education (such as utility gains from higher life expectancy or lower chances of displacement) simply reinforces this conclusion.

If average gains from an additional year of high school exceed forgone earnings many times over, what could explain dropout behavior within an investment model? I offer four possibilities. The first is that dropouts abhor school. Poor classroom performance and condescending attitudes from students and teachers may make students want to leave as soon as possible, even at the expense of forgoing large monetary sums. Removing reasons for school distaste could go a long way in reducing dropout rates [Lee and Burkam (2003)]. The level of distaste among would-be dropouts in the 1990 Eurobarometer Youth Survey, however, seems small. Just over 90 percent of British 15 year-olds expecting to leave school at age 16 report being satisfied or very satisfied with their overall lives, compared to 94 percent of British 15 year-olds expecting to leave later. For the sample aged 16 and not in school, the fraction reporting life satisfaction actually falls to 80 percent, while the fraction for 16 year-olds that did not leave remains at 91 percent. $^{21}$

A second possibility is that students or parents are financially constrained. They cannot borrow off of higher expected future earnings to prevent low levels of consumption while attending school.

\footnotetext{
${ }^{21}$ The Eurobarometer Surveys are available through UK Data Archive. They began in 1970 to track opinions and attitudes among members of the European Community. 1990 Eurobarometer Youth Survey asks a nationally representative sample of 15 to 24 year olds questions about school choice decisions and life satisfaction. The question posed was, "On the whole, are you very satisfied, fairly satisfied, not very satisfied, or not at all satisfied with the life you lead?".
} 
Students may desire to leave home, or parents may not be able to support their children another year. If financial constraints matter, policies that provide monetary support to youths at risk of dropping out may help them stay on to realize larger rewards. For example, Dearden, et al. (2003) examine a pilot experiment in Britain that paid 16 to 18 year-olds from low-income families $£ 30$ per week, plus retention bonuses, for remaining in school past Grade 11. Comparing with a randomized control group, the program reduced early dropout rates by 5.9 percentage points, from 34.5 percent to 28.7 percent. This result may not necessarily be driven from relaxing credit constraints. Of those who dropped out, more than half were not working. Similarly, among 17 year-olds not in school in the 2000 U.S. Census, 90.4 percent lived with parents, and 45 percent were not in the labor force.

A related third explanation for dropout behavior is that youths want to invest in additional education but parents are not willing to bear the costs - not because they are credit constrained but because they cannot be sure of recovering those costs. The argument relates to a recent literature explaining the rationale behind child labor law policies in developing countries. Baland and Robinson [2000], for example, point out, "if children could borrow when they were young, they could transfer resources to their parents and compensate them for reduced child labor, even if parents subsequently planned to leave no bequests. Alternatively, children could enter into a contract with their parents involving a transfer of future income in exchange for a current reduction in child labor. However, such contracts are in general neither self-enforcing nor legally enforceable". Institutional arrangements that compensate parents for their investment with future resources from children may make all better off.

A fourth explanation why dropouts choose not to invest in education is that the risks are too high. A better depiction of the school-choice decision involves deciding between alternative earnings distributions. If a student is risk-averse, higher expected returns from additional schooling may not be enough to offset higher probabilities of earning particularly low wages [Levhari and Weiss, 1974, Chen, 2002]. Judd (2002) applies the Capital Asset Pricing Model to determine whether the risk-return relationship for education is similar to that for comparable assets. He concludes that the risk associated 
from an education investment is much lower than the risk associated with other assets with similar expected returns. Furthermore, it seems unlikely a student would end up significantly worse off from staying in high school than from dropping out. More likely, the alternative distribution from staying on stochastically dominates.

\section{B. Compulsory School Laws Should Stay}

I provide below three additional explanations for dropout behavior. Unlike the previous ones, these imply compulsory school laws may increase welfare, at least on average.

The first alternative explanation to dropout behavior is that students ignore future consequences of present decisions. A high time preference rate leads students to place more weight on the immediate attendance costs of school and less weight on future outcomes such as health and earnings (that cannot be transferred to the present). ${ }^{22}$ Discounting future consequences from immediate actions does not imply myopic behavior unless such discounting occurs temporarily. Students that temporarily downplay future consequences (as considered by Laibson (1997) and O’Donoghue and Rabin (1999)) may prefer dropping out to staying on but later prefer staying on to dropping out. For example, when asked whether leaving high school was a good decision, 52.9 percent of dropouts from the U.S. High School and Beyond Survey said no. ${ }^{23}$ Compulsory school laws are often motivated by wanting to prevent these types of responses.

A second alternative explanation to dropout behavior considers influences from social or cultural identity. A central theme from the works of Akerlof and Kranton (2000,2002), Coleman (1961), Cusick (1972), Everhart (1983), Gordon (1957), Hall (1904), Hollingshead (1975), Jackson (1968), Roderick

\footnotetext{
${ }^{22}$ A high time preference rate does not affect dropout behavior without the presence of credit constraints or non-pecuniary costs or benefits from schooling. If none of these cases are present, students that prefer to consume more in the present can simply borrow off of future earnings. [see Oreopoulos, 2003].

${ }^{23}$ The question, "On the whole, do you feel that leaving school was a good decision for you?" was asked to 2,208 respondents who left high school without graduation in the dropout questionnaire of the third follow-up to the sophomore High School and Beyond Survey [ICPSR, 2003]. 37.7 percent responded yes, 42.4 percent responded no, 19.9 percent did not respond or said 'Don't Know'.
} 
(1993), and Willis (1977) is that adolescent concerns about self-image or peer acceptance predominate adolescent behavior. Lack of emotional support or acceptance may exacerbate students' distaste for continuing school beyond the minimum age. Raising the school leaving age would obviously remove this distaste, since parents or peers can no longer attribute the higher attainment outcome to a student's choice. A student's same-aged peers would also face the higher age restrictions, removing any disutility from being in school while others are not. Combining the first and second alternative explanations, students

may place temporarily high weight on immediate social or cultural considerations, while downplaying these factors only after a choice is made.

A final consideration is that students may simply mispredict. They may make incorrect present value calculations of future returns, or underestimate the real gains from school. Dominitz and Manski (2000) find substantial variation among high school students in earnings expectations conditional on a bachelor degree. While expectations about the returns from a degree were positive, it seems questionable whether would-be-dropouts can anticipate lifetime gains from one more year of school. Guidance from parents who themselves dropped out or peers that do not care for school may also lead to misinformation.

\section{Conclusion}

This paper uses changes in school leaving laws to measure forgone benefits from dropping out. I compare results across the U.S., Canada, and the U.K. Changes to these laws in all three countries lead to remarkably similar effects. Students compelled to take an extra year of schooling experienced an average increase of 10 to 14 percent in wages. I also find significant gains from education to health measures, employment, and poverty status. The results hold up against many specifications checks and are entirely consistent with previous studies.

The main conclusion of this paper is that the opportunity cost to dropping out is very large. My estimates range from about 2 to 3 times a dropouts' peak lifetime annual wage or 6 to 12 times a 
dropouts' forgone earnings. The results offer important perspectives for evaluating school leaving decisions. Knowing what forgone benefits are from dropping out helps quantify a cost-benefit analysis of the dropout decision and narrow down possible explanations for leaving.

In the absence of significant positive externalities, viewing education as an investment suggests compulsory schooling laws should not exist, since the laws place constraints on individuals already optimizing. As an investment, the results imply school attendance costs would have to be extremely large to explain dropout decisions. If true, addressing these costs could mitigate dropout behavior.

On the other hand, it seems reasonable to suggest the possibility that a dropout's one-year attendance costs are not enough to offset this paper's predicted gains from staying on. Perhaps other explanations would be better suited for explaining dropout behavior. There is no a priori reason to prefer an investment model of school attainment over the many other possibilities - cultural or peer pressures may predominate adolescent decision-making; youths may underestimate the rewards from staying in school; they may temporarily ignore longer-term consequences of their decisions; or parents may not be able to recover costs off of their children's gains. Each explanation carries vastly different policy implications. The potential to improve a large set of social and economic outcomes certainly seems to merit further investigation. 


\section{References}

Acemoglu, Daren and Joshua Angrist. "How Large Are Human Capital Externalities? Evidence from Compulsory Schooling Laws," NBER Macroannual, 2000, pp. 9-59.

Akerlof, George and Rachael Kranton, "Identity and Schooling: Some Lessons for the Economics of Education," Journal of Economic Literature, No. 40, Vol. 4 (December), 2002, pp. 1167-1201.

Angrist, Joshua D., and Alan Krueger. "Does Compulsory School Attendance Affect Schooling and Earnings?" Quarterly Journal of Economics, Vol. 106, No. 4, pp. 979, 1014, 1991.

Angrist, Joshua D., Guido W. Imbens and Donald B. Rubin, "Identification of Causal Effects Using Instrumental Variables," Journal of the American Statistical Association, June 1996.

Baland, Jean-Marie, and James A. Robinson, "Rotten Parents," Journal of Public Economics, Vol. 84, 2002, pp. 341-356.

Barnard, H.C. “A History of English Education,” University of London Press, Bungay, Suffolk, 1961.

Chen, Stacey H. "Is Investing in College Education Risky?", mimeo, Department of Economics, State University of New York at Albany, 2002.

Chiswick, Barry R. "Minimum Schooling Legislation and the Cross-Sectional Distribution of Income," The Economic Journal, Vol. 79, No. 315. (Sep., 1969), pp. 495-507.

Coleman, James S. “The Adolescent Society,” The Free Press, New York, 1961.

Cook, Philip J. and Jens Ludwig. "Weighing the 'Burden of 'Acting White'": Are There Race Differences in Attitudes Towards Education?", Journal of Policy Analysis and Management, Vol. 16, No. 2, pp. 256$278,1997$.

Cusick, Philip. “Inside High School,” Holt, Rinehart, and Winston, New York, 1972.

Dearden, Lorraine, Carl Emmerson, Christine Frayne, and Costas Meghir, "The Impact of Financial Incentives on Educational Choice," Institute for Fiscal Studies Mimeo, 2002.

Dent, Harold C. "Growth in English Education: 1946-1952," Routledge and Kegan Paul, London, 1954.

Dent, Harold C. “The Education Act: 1944,” University of London Press, London, 1957.

Dent, Harold C. "1870-1970 Century of Growth in English Education," Longman Group Limited, London, 1970.

Dent, Harold C. “The Educational System of England and Wales,” University of London Press, 1971.

Dominitz, Jeff, and Charles F. Manski. "Using Expectations Data to Study Subjective Income Expectations," Journal of the American Statistical Association, 92, No. 439, pp. 855-867, 2000. 
Durcan, Thomas J. "History of Irish Education from 1800,” Dragon Books, Bala, North Wales, 1972.

Eckstein, Zvi, and Kenneth I. Wolpin, "Why Youths Drop Out of High School: The Impact of Preferences, Opportunities, and Abilities," Econometrica, Vol. 67, No. 6, 1999, pp. 1295-1339.

Everhart, Robert B. "Reading, Writing and Resistance: Adolescence and Labor in a Junior High School," Routledge and Kegan Paul, Boston, 1983.

Gatto, John Taylor, "Dumbing Us Down: The Hidden Curriculum of Compulsory Schooling," Gabriola Island, B.C.: New Society Publishers, 2002.

Goldin, Claudia and Lawrence F. Katz, "Mass Secondary Schooling and the State: The Role of State Compulsion in the High School Movement," NBER Working Paper \#10075, 2003

Gordon, Wayne C. "The Social System of the High School,” The Free Press, Chicago, 1957.

Gosden, P.H.J.H. "How They Were Taught,” Basil Blackwell, Oxford, 1969.

Halsey, A.H., A.F. Heath, and J.M. Ridge, Origins and Destinations, Clarendon Press, Oxford, U.K., 1980.

Hall, Stanley G. “Adolescence,” Appleton, New York, 1904.

Halsey, A.H., A.F. Heath and J.M. Ridge. "Origins and Destinations: Family, Class, and Education in Modern Britain,” Clarendon Press, Oxford, 1980.

Harmon, Colm, and Ian Walker. "Estimates of the Economic Return to Schooling for the United Kingdom,” American Economic Review, December 1995, pp. 1278-86.

Jackson, Philip. “Life in Classrooms,” Holt, Rinehart, and Winston, New York, 1968.

Judd, Kenneth L. "Is Education as Good as Gold? A Portfolio Analysis of Human Capital Investment," Stanford Economics Department Mimeo, 2000.

Laibson, David. "Golden Eggs and Hyperbolic Discounting," Quarterly Journal of Economics, Vol. 112(2), 1997, pp. 443-77.

Lang, K. and Kropp, D. "Human Capital vs. Sorting: The Effect of Compulsory Attendance Laws," Quarterly Journal of Economics 101 (August 1986): 609-624

Lee, Valerie E., and David T. Burkam, "Dropping Out of High School: The Role of School Organization and Structure," American Educational Research Journal, Vol. 40, No. 2 (Summer), 2003, pp. 353-393.

Levhari, David and Yoram Weiss. "The Effect of Risk on the Investment in Human Capital," American Economic Review, Vol. 64, No. 6, pp. 950-63, 1974.

Lleras-Muney, Adriana. "The Relationship Between Education and Adult Mortality in the United States," NBER Working Paper No. 8986, 2002. 
Lleras-Muney, Adrianna, "Were Compulsory Attendance and Child Labor Laws Effective? An Analysis from 1915 to 1939," Journal of Law and Economics Vol. 45 (October), 2002, pp. 401-35.

Lochner, Lance, and Enrico Moretti. "The Effect of Education on Crime: Evidence from Prison Inmates, Arrests, and Self-Reports," American Economic Review, forthcoming, 2003.

Loewenstein, George, Ted O'Donoghue, and Mathew Rabin, "Projection Bias in Predicting Future Utility," Quarterly Journal of Economics, forthcoming, 2003.

Machan, Tibor R., "Education in a Free Society," Stanford, CA: Hoover Institution Press, Stanford University, 2000.

O’Donoghue, Ted, and Matthew Rabin. "Risky Behavior among Youths: Some Issues from Behavioral Economics," in Risky Behavior Among Youths, Gruber, Jonathan (ed.), University of Chicago Press, Chicago, 2001, pp. 29-68.

Oreopoulos, Philip. "Do Dropouts Drop Out Too Soon? Evidence Using Changes in School-Leaving Laws,” Institute for Policy Analysis Working Paper No. 145, 2003 a.

Oreopoulos, Philip. “The Compelling Effects of Compulsory Schooling: Evidence from Canada,” Mimeo, University of Toronto, 2003b.

Park, Jin Heum, "Estimation of Sheepskin Effects and Returns to Schooling Using the Old and New CPS Measures of Educational Attainment," Princeton Industrial Relations Section Working Paper No. 338, December, 1994.

Rickenbacker, Willian F. (ed.), “The Twelve-year Sentence,” LaSalle, III., Open Court, 1974.

Roderick, Melissa. "The Path to Dropping Out,” Auburn House, WestportMA, 1993.

Schmidt, Stefanie, "School Quality, Compulsory Education Laws, and the Growth of American High School Attendance, 1915-1935," MIT Ph.D. Dissertation, 1996.

Willis, Paul. “Learning to Labour,” Saxon House, Westmead, 1977.

Wolf, Alison, “Does Education Matter?” Milken Institute Review, December 2002. 
Figure 1

Minimum School Leaving Ages in the U.S. by State

1915 - 1975
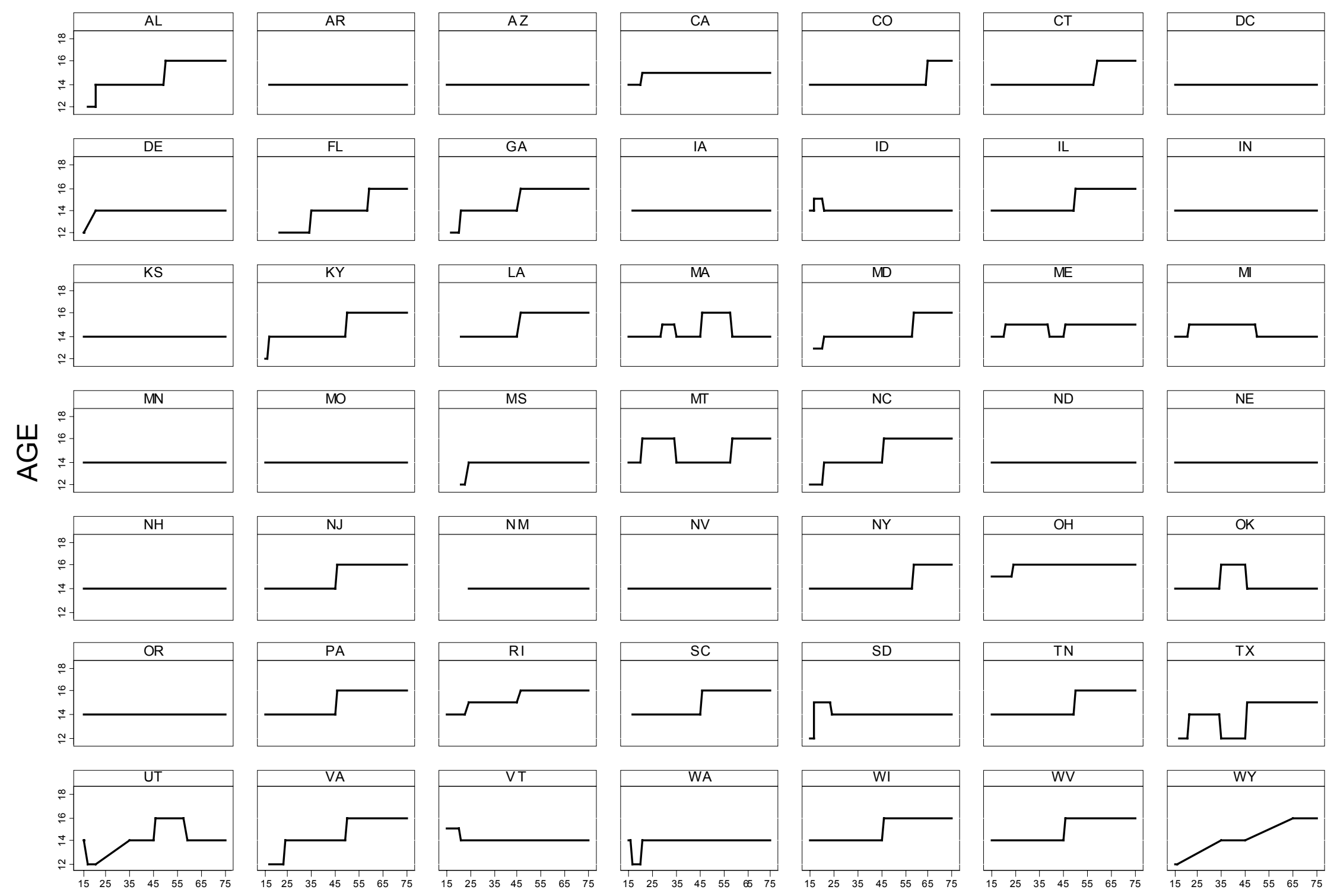

Graphs by state abbreviation 
Figure 2

Minimum School Leaving Ages in Canada by Province

1925 - 1975
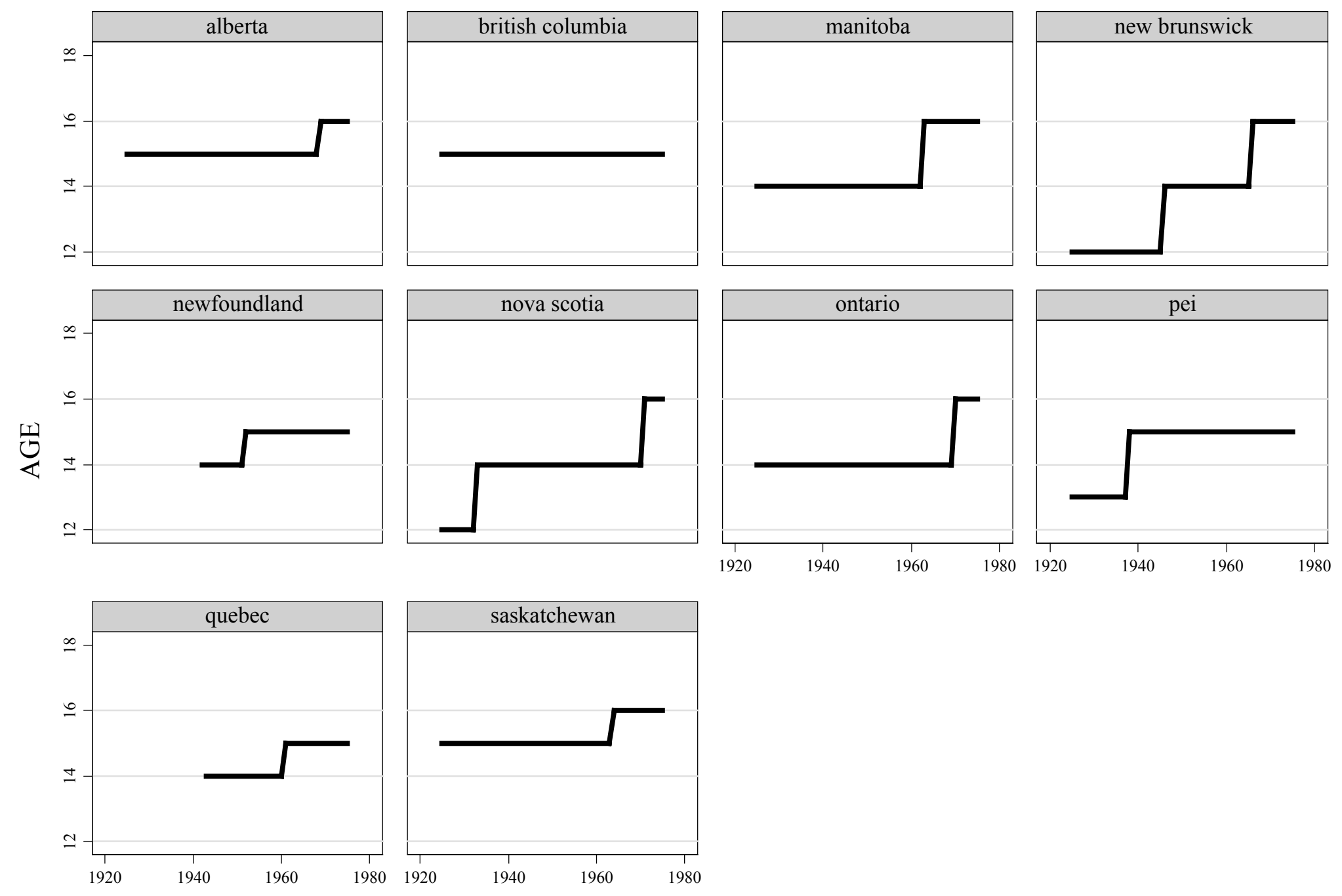

Graphs by provname 
Figure 3A

Fraction Left Full-Time Education by Year Aged 14 and 15 Great Britain

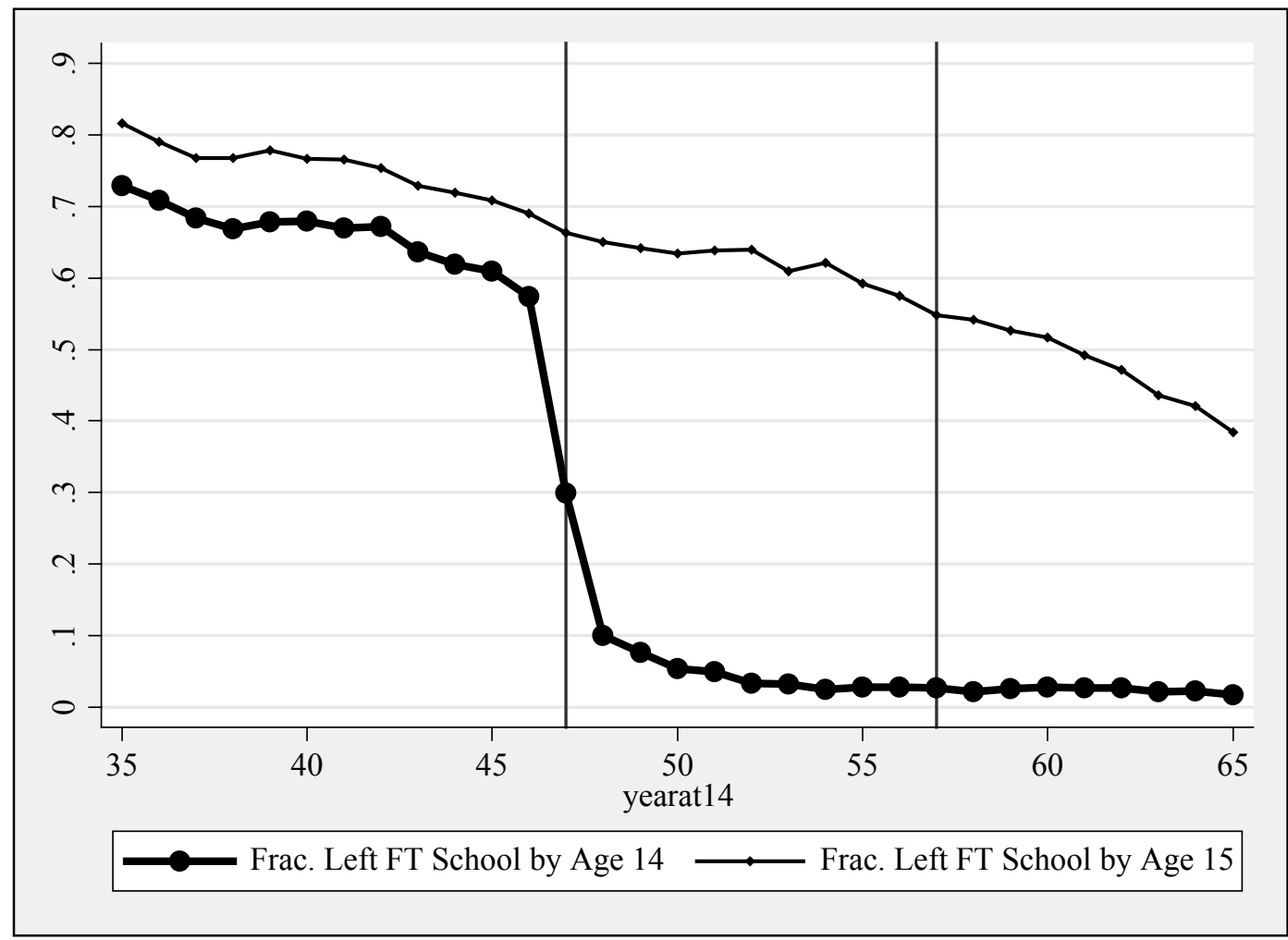

Notes: The lower line shows the proportion of British-born adults aged 16 to 64 from the 1983 to 1998 General Household Surveys who report leaving full-time education at, or before, age 14. The upper line shows the same, but for age 15 . 
Figure 3B

Fraction Left Full-Time Education by Year Aged 14 and 15 Northern Ireland

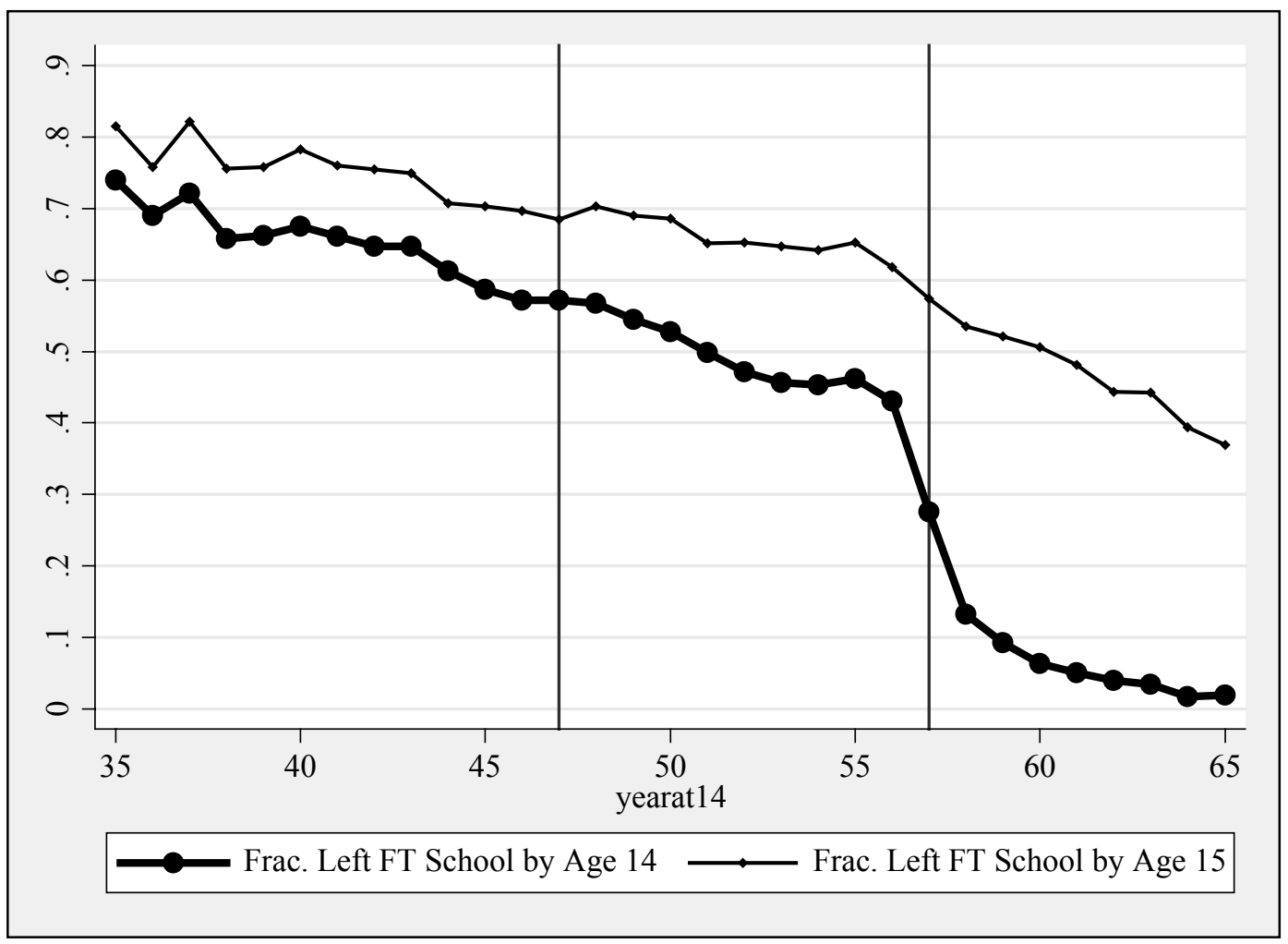

Notes: The lower line shows the proportion of Northern Irish adults aged 16 to 64 from the 1985 to 1998 Continuous Household Surveys who report leaving full-time education at, or before, age 14. The upper line shows the same, but for age 15 . 
Figure 4A

Adult Education Attainment and Earnings for Cohorts Aged 14 Before and After Increases in the Minimum School Leaving Age

\section{USA}

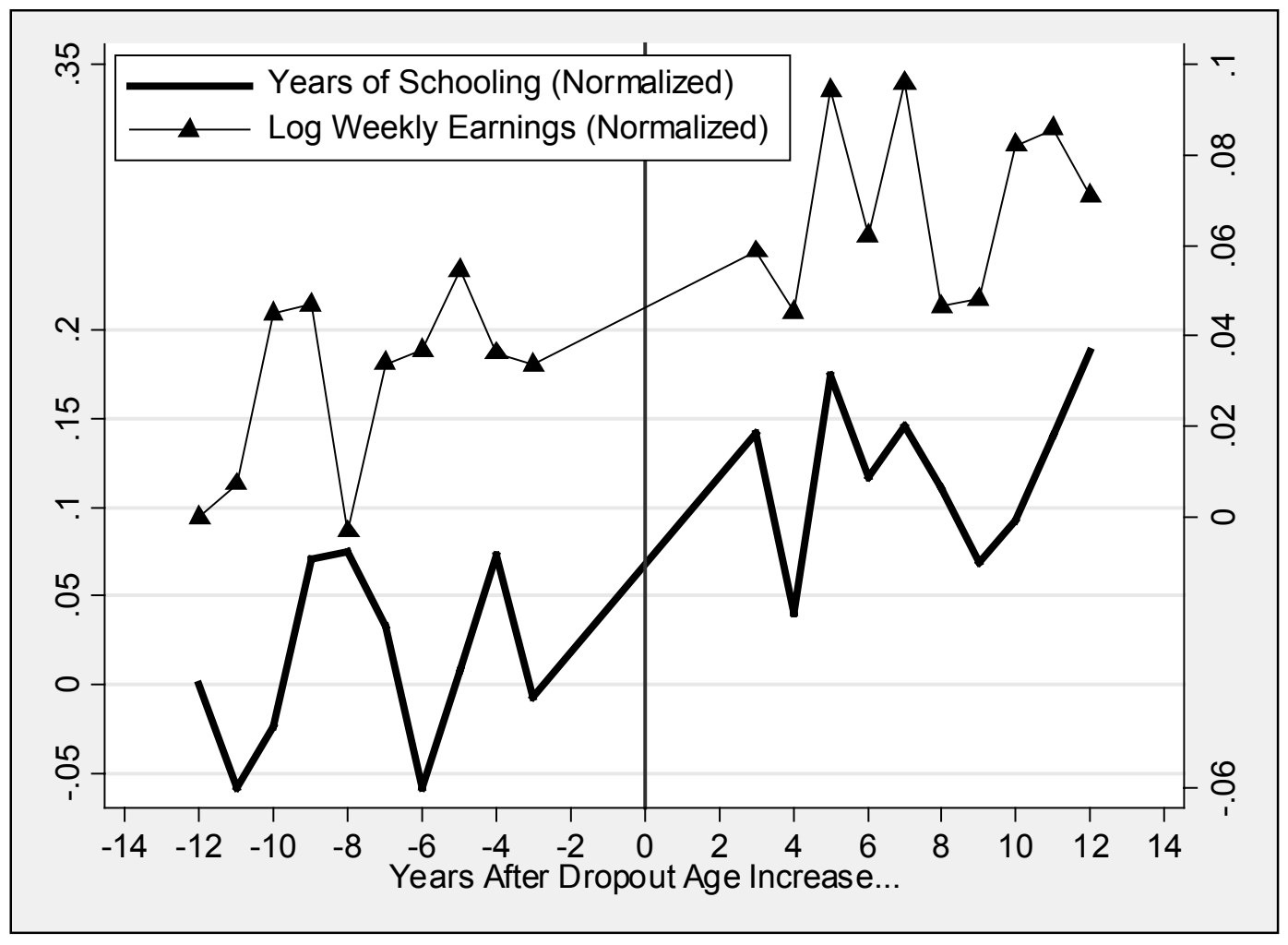

Notes: The U.S. high school dropout data extract discussed in Section III was aggregated into state and birth cohort cell means, weighted by population size. Average total years of schooling and log weekly earnings were regressed on indicators for the number of years between an increase in a state's minimum school leaving age and the year a cohort was 14, plus state and birth cohort fixed effects. The time indicator coefficients are shown, normalized to zero for the group that was 14 years-old 12 years before an increase. 
Figure 4B

Adult Education Attainment and Earnings for Cohorts Aged 14 Before and After Increases in the Minimum School Leaving Age

\section{Canada}

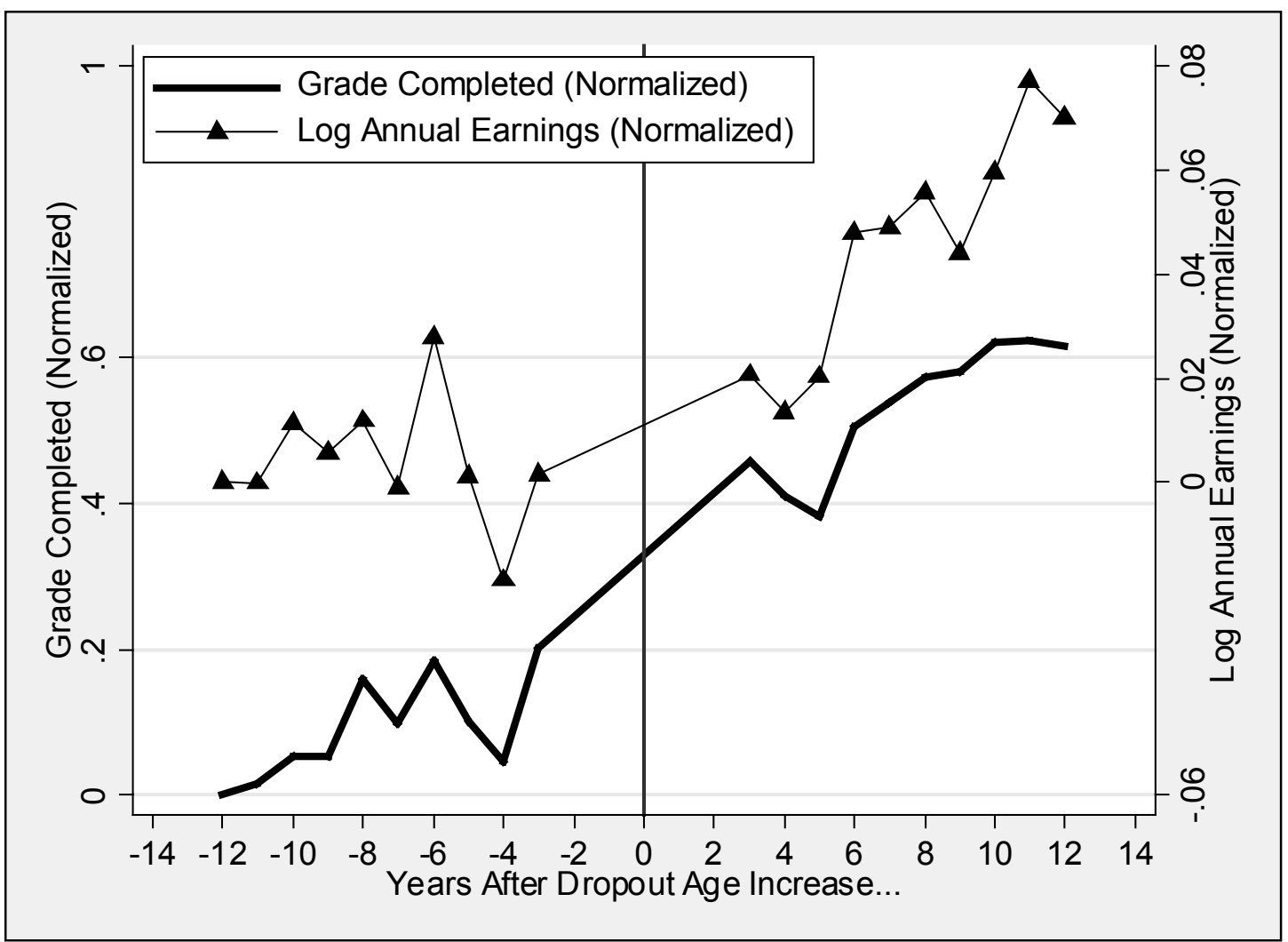

Notes: The Canadian high school dropout data extract discussed in Section III was aggregated into province and birth cohort cell means, weighted by population size. Average high school grade attainment and log annual earnings were regressed on indicators for the number of years between an increase in a province's minimum school leaving age and the year a cohort was 14, plus province and birth cohort fixed effects. The time indicator coefficients are shown, normalized to zero for the group that was 14 years-old 12 years before an increase. 
Figure 4C

Adult Education Attainment and Earnings for Cohorts Aged 14 Before and After Increases in the Minimum School Leaving Age

\section{United Kingdom}

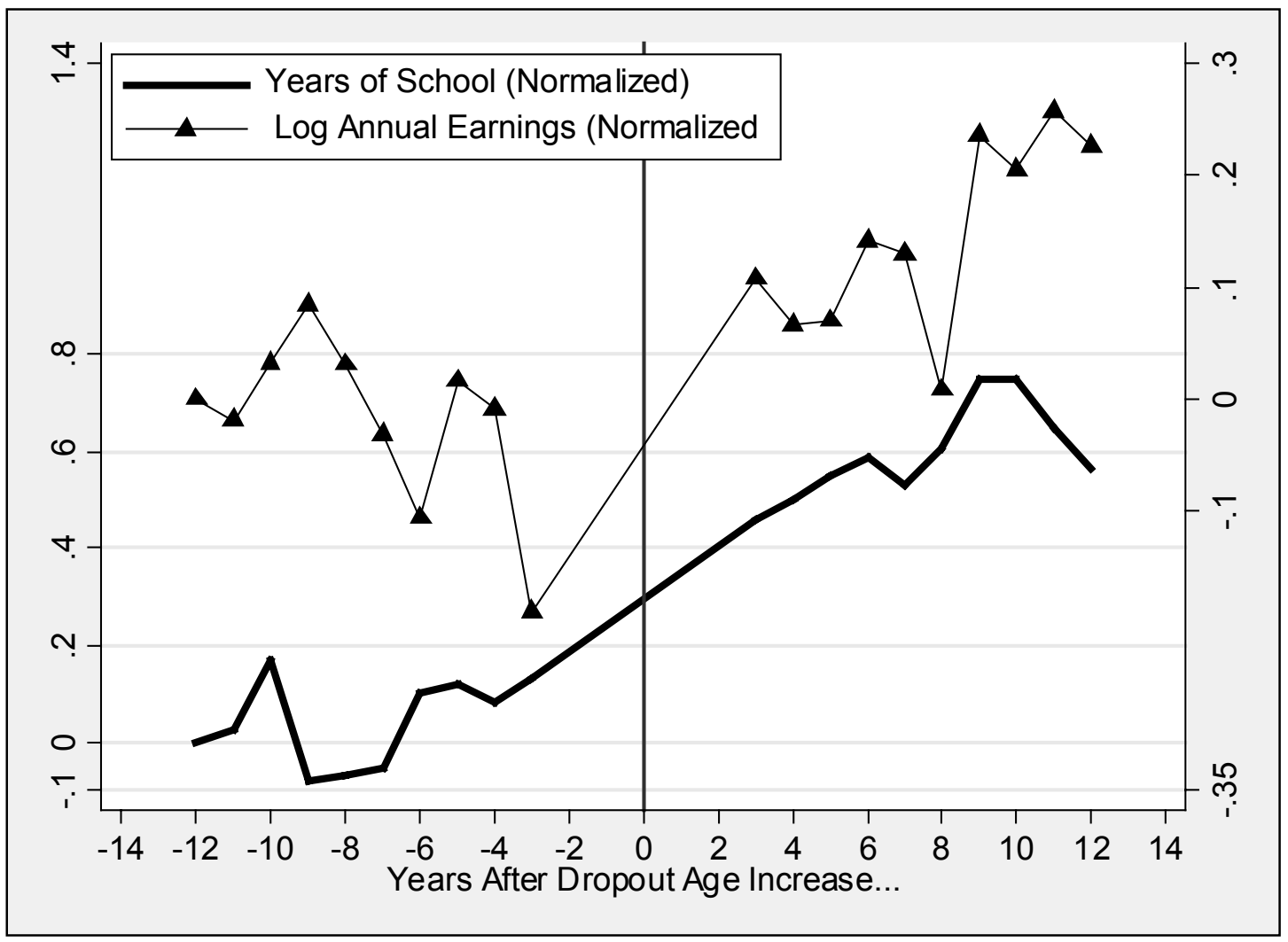

Notes: The U.K. high school dropout data extract discussed in Section III was aggregated into region (Britain/N.Ireland) and birth cohort cell means, weighted by population size. Cell means were calculated using the sample of 25 to 64 year-olds who were age 14 between 1935 and 1985 . Average high school grade attainment and log annual earnings were regressed on indicators for the number of years between an increase in a region's minimum school leaving age and the year a cohort was 14, plus region and birth cohort fixed effects. The time indicator coefficients are shown, normalized to zero for the group that was 14 years-old 12 years before an increase. 
Figure 5

Projected Annual Earnings Profiles for Males Leaving School at Ages 15 and 16

(2000 U.S. Dollars)

A. United States

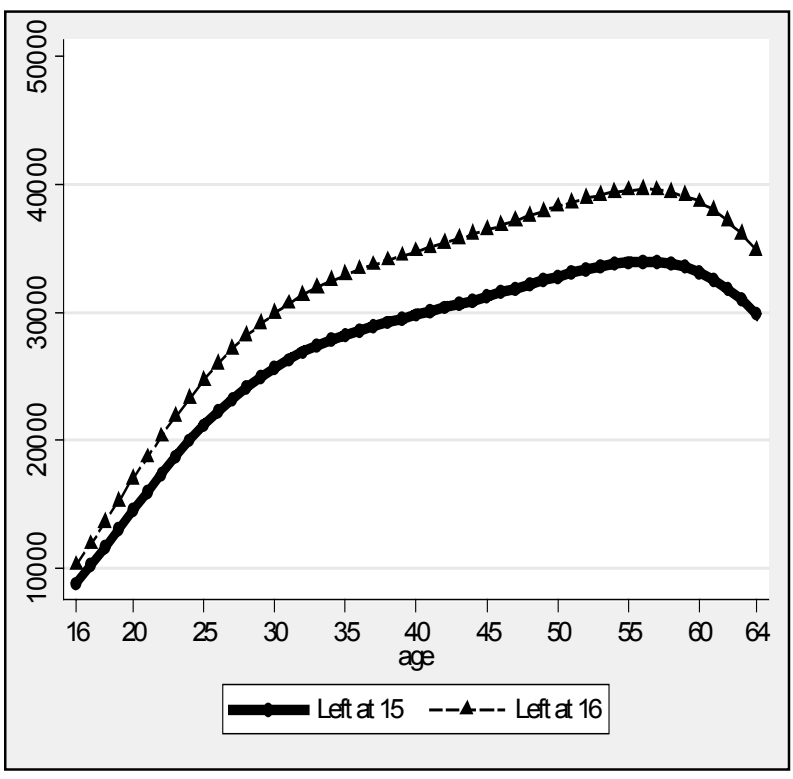

B. Canada

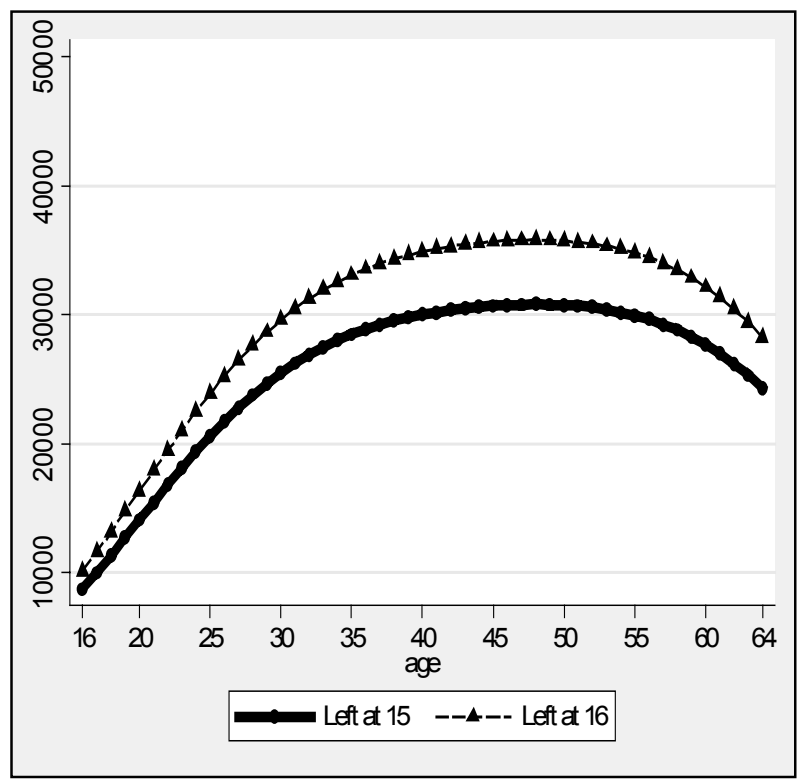

C. United Kingdom

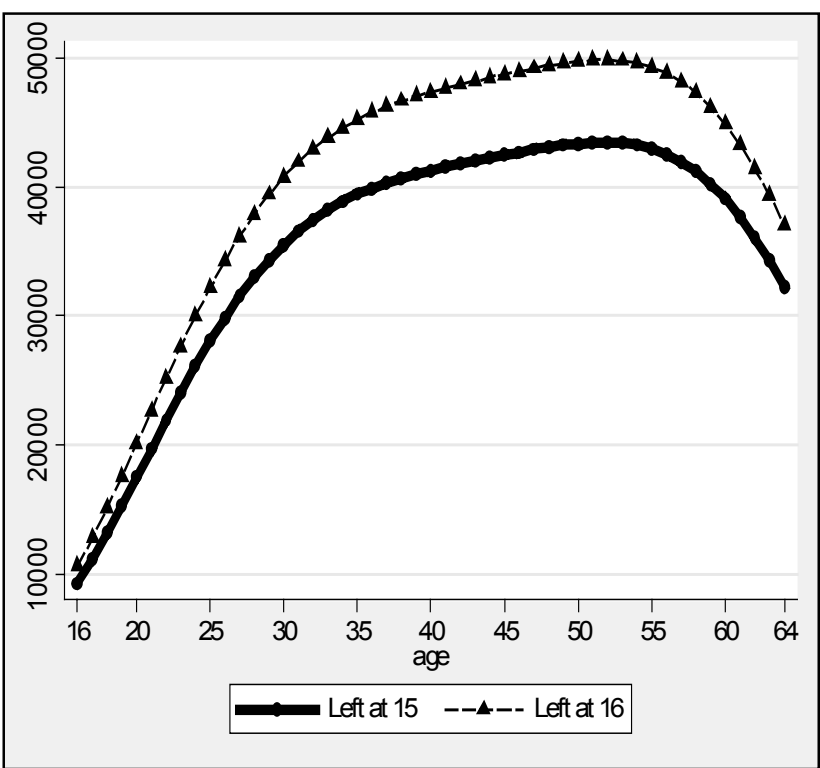

Notes: Each figure uses quartic age coefficients, returns to compulsory schooling estimates, and a baseline wage of $\$ 7,525$ for 15 -year old dropouts at age 15 (the average wage among 17 year old male dropouts working full-time in the 2000 U.S. Census) to generate the profiles. For the U.S. and Canada, the coefficients were generated using the same results in Table 3 for male high school dropouts, except that the regression samples included dropouts aged 15 to 64 not in school instead of dropouts age 25 to 64 . For the U.K., the sample included all 15 to 64 year-old males in the 1983 to 1998 GHHS that left full-time school before age 18 . Log annual earnings were regressed on years of schooling, instrumented by the minimum leaving age faced when in school, a quartic in age, and fixed effects for survey year, and whether living in Northern Ireland. the manufacturing sector, female, and average age. Data were grouped into means by birth year, Northern Ireland, sex, and survey year and weighted by cell population size. See text for more details. 
Table 1

First Stage Effects of Compulsory Schooling on Education Attainment and Earnings for the U.S., Canada, and the U.K.

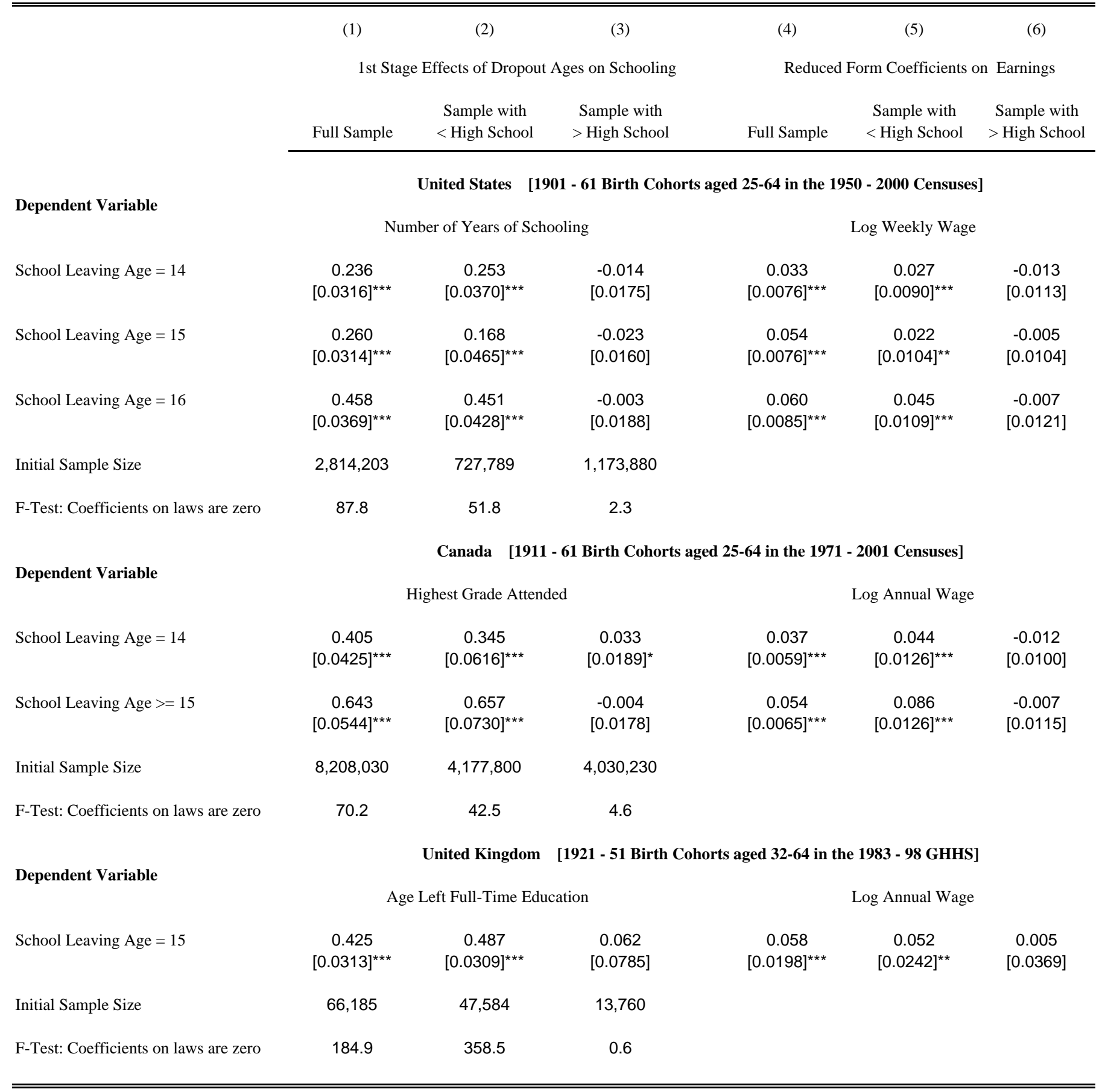

Notes: All regressions include fixed effects for birth year, region (state, province, Britain/N.Ireland), survey year, sex, and a quartic in age. The U.S. results also include a dummy variable for race and state controls for fraction living in urban areas, fraction black, in the labor force, in the manufacturing sector, female, and average age based on when a birth cohort was age 14. Similar province controls for Canada include fraction in urban areas, fraction in the manufacturing sector, female, and average age. Data are grouped into means by birth year, nation, sex, race (for the U.S.) and survey year and weighted by cell population size. Huber-White standard errors are shown from clustering by region and birth cohort. Single, double, and triple asterix indicate significant coefficients at the 10 percent, 5 percent, and 1 percent levels respectively. The ommited variable indicates whether able to drop out at age 13 or less for the U.S. and Canada, and 14 or less for the U.K. Samples include all adults aged 25 to 64 . Dependent variable in Column 3 for Canada is $1=$ some post secondary schooling, 0 otherwise. See text for more data specifics. 
Table 2

\section{Estimated Effects of Own School Leaving Age and Later Birth Cohorts' School Leave Age on Education Attainment and Earnings}

\begin{tabular}{|c|c|c|c|c|c|c|}
\hline \multirow{5}{*}{$\begin{array}{l}\text { Lead Year for } \\
\text { School Leaving Age } \\
\text { Faced by Later Birth } \\
\text { Cohort }\end{array}$} & $(1)$ & (2) & (3) & (4) & $(5)$ & $(6)$ \\
\hline & \multicolumn{6}{|c|}{ United States $\quad$ [1901 - 61 Birth Cohorts aged 25-64 in the 1950 - 2000 Censuses] } \\
\hline & \multicolumn{2}{|c|}{$\begin{array}{l}\text { First Stage Dep. Var. } \\
\text { Years of Schooling }\end{array}$} & \multicolumn{2}{|c|}{$\begin{array}{l}\text { Reduced form Dep. Var. } \\
\text { Log Weekly Earnings }\end{array}$} & \multicolumn{2}{|c|}{$\begin{array}{l}\text { IV: Estimates of } \\
\text { Returns to Comp. Schooling }\end{array}$} \\
\hline & School Leaving & Later School & School Leaving & Later School & Years of & Later School \\
\hline & Age & Leaving Age & Age & Leaving Age & Schooling & Leaving Age \\
\hline none & $\begin{array}{c}0.099 \\
{[0.0067]^{\star * *}}\end{array}$ & & $\begin{array}{c}0.015 \\
{[0.0015]^{\star * *}}\end{array}$ & & $\begin{array}{c}0.151 \\
{[0.0130]^{\star * *}}\end{array}$ & \\
\hline 2 years & $\begin{array}{c}0.114 \\
{[0.0099]^{\star \star \star}}\end{array}$ & $\begin{array}{c}-0.016 \\
{[0.0077]^{\star *}}\end{array}$ & $\begin{array}{c}0.016 \\
{[0.0021]^{\star \star *}}\end{array}$ & $\begin{array}{c}-0.001 \\
{[0.0015]}\end{array}$ & $\begin{array}{c}0.141 \\
{[0.0147]^{\star \star *}}\end{array}$ & $\begin{array}{c}0.001 \\
{[0.0011]}\end{array}$ \\
\hline \multirow[t]{2}{*}{3 years } & $\begin{array}{c}0.103 \\
{[0.0088]^{\star \star \star}}\end{array}$ & $\begin{array}{c}-0.005 \\
{[0.0072]}\end{array}$ & $\begin{array}{c}0.014 \\
{[0.0019]^{\star \star \star}}\end{array}$ & $\begin{array}{c}0.001 \\
{[0.0014]}\end{array}$ & $\begin{array}{c}0.139 \\
{[0.0160]^{\star \star \star}}\end{array}$ & $\begin{array}{c}0.001 \\
{[0.0013]}\end{array}$ \\
\hline & \multicolumn{6}{|c|}{ Canada [1911 - 61 Birth Cohorts aged 25-64 in the 1971 - 2001 Censuses] } \\
\hline Lead Year for & \multicolumn{2}{|c|}{$\begin{array}{l}\text { First Stage Dep. Var. } \\
\text { Highest Grade Attended }\end{array}$} & \multicolumn{2}{|c|}{$\begin{array}{l}\text { Reduced form Dep. Var. } \\
\text { Log Annual Earnings }\end{array}$} & \multicolumn{2}{|c|}{$\begin{array}{c}\text { IV: Estimates of } \\
\text { Returns to Comp. Schooling }\end{array}$} \\
\hline $\begin{array}{l}\text { Faced by Later Birth } \\
\text { Cohort }\end{array}$ & $\begin{array}{l}\text { School Leaving } \\
\text { Age }\end{array}$ & $\begin{array}{l}\text { Future School } \\
\text { Leaving Age }\end{array}$ & $\begin{array}{l}\text { School Leaving } \\
\text { Age }\end{array}$ & $\begin{array}{l}\text { Future School } \\
\text { Leaving Age }\end{array}$ & $\begin{array}{l}\text { Highest Grade } \\
\text { Attended } \\
\end{array}$ & $\begin{array}{l}\text { Future School } \\
\text { Leaving Age }\end{array}$ \\
\hline none & $\begin{array}{c}0.374 \\
{[0.0489]^{* * *}}\end{array}$ & & $\begin{array}{c}0.051 \\
{[0.0092]^{\star * *}}\end{array}$ & & $\begin{array}{c}0.135 \\
{[0.0181]^{* * *}}\end{array}$ & \\
\hline 2 years & $\begin{array}{c}0.355 \\
{[0.0601]^{* * *}}\end{array}$ & $\begin{array}{c}0.034 \\
{[0.0563]}\end{array}$ & $\begin{array}{c}0.044 \\
{[0.0098]^{* * *}}\end{array}$ & $\begin{array}{c}0.012 \\
{[0.0107]}\end{array}$ & $\begin{array}{c}0.124 \\
{[0.0187]^{\star * \star}}\end{array}$ & $\begin{array}{c}0.007 \\
{[0.0071]}\end{array}$ \\
\hline \multirow[t]{2}{*}{3 years } & $\begin{array}{c}0.358 \\
{[0.0554]^{* * *}}\end{array}$ & $\begin{array}{c}0.037 \\
{[0.0535]}\end{array}$ & $\begin{array}{c}0.042 \\
{[0.0094]^{\star \star \star}}\end{array}$ & $\begin{array}{c}0.019 \\
{[0.0111]^{*}}\end{array}$ & $\begin{array}{c}0.118 \\
{[0.0175]^{\star * *}}\end{array}$ & $\begin{array}{c}0.014 \\
{[0.0074]^{*}}\end{array}$ \\
\hline & \multicolumn{4}{|c|}{ United Kingdom } & he 1983 - $98 \mathrm{C}$ & HS] \\
\hline Lead Year for & \multicolumn{2}{|c|}{$\begin{array}{l}\text { First Stage Dep. Var. } \\
\text { Highest Grade Attended }\end{array}$} & \multicolumn{2}{|c|}{$\begin{array}{l}\text { Reduced form Dep. Var. } \\
\text { Log Annual Earnings }\end{array}$} & \multicolumn{2}{|c|}{$\begin{array}{c}\text { IV: Estimates of } \\
\text { Returns to Comp. Schooling }\end{array}$} \\
\hline $\begin{array}{l}\text { Faced by Later Birth } \\
\text { Cohort }\end{array}$ & $\begin{array}{l}\text { School Leaving } \\
\text { Age } \\
\end{array}$ & $\begin{array}{c}\text { Future School } \\
\text { Leaving Age }\end{array}$ & $\begin{array}{l}\text { School Leaving } \\
\text { Age }\end{array}$ & $\begin{array}{c}\text { Future School } \\
\text { Leaving Age }\end{array}$ & $\begin{array}{l}\text { Highest Grade } \\
\text { Attended }\end{array}$ & $\begin{array}{c}\text { Future School } \\
\text { Leaving Age }\end{array}$ \\
\hline none & $\begin{array}{c}0.425 \\
{[0.0313]^{\star * *}}\end{array}$ & & $\begin{array}{c}0.058 \\
{[0.0198]^{\star \star \star}}\end{array}$ & & $\begin{array}{c}0.158 \\
{[0.0491]^{\star \star \star}}\end{array}$ & \\
\hline 2 years & $\begin{array}{c}0.484 \\
{[0.0380]^{* * *}}\end{array}$ & $\begin{array}{c}-0.100 \\
{[0.0393]^{* *}}\end{array}$ & $\begin{array}{c}0.072 \\
{[0.0233]^{\star * *}}\end{array}$ & $\begin{array}{c}-0.023 \\
{[0.0257]}\end{array}$ & $\begin{array}{c}0.176 \\
{[0.0577]^{* * *}}\end{array}$ & $\begin{array}{c}-0.011 \\
{[0.0233]}\end{array}$ \\
\hline 3 years & $\begin{array}{c}0.477 \\
{[0.0318]^{\star \star *}}\end{array}$ & $\begin{array}{c}-0.119 \\
{[0.0342]^{\star \star *}}\end{array}$ & $\begin{array}{c}0.073 \\
{[0.0192]^{\star \star \star}}\end{array}$ & $\begin{array}{c}-0.032 \\
{[0.0223]}\end{array}$ & $\begin{array}{c}0.179 \\
{[0.0463]^{\star \star *}}\end{array}$ & $\begin{array}{c}-0.017 \\
{[0.0202]}\end{array}$ \\
\hline
\end{tabular}

Notes: Each row in columns 1 and 2 show the first stage coefficients from regressing own school leaving age and a later cohort's school leaving age on education attainment. Columns 3 and 4 show the reduced form coefficients from regressing own school leaving age and a later cohort's school leaving age on earnings. Columns 5 and 6 show the coefficients from the instrumental variables estimate of the returns to compulsory schooling and the lead school leaving age control. All regressions include fixed effects for birth year, region (state or province), survey year, sex, and a quartic in age. The U.S. results also include a dummy variable for race and state controls for fraction of state living in urban areas, fraction black, in the labor force, in the manufacturing sector, female, and average age based on when a birth cohort was age 14. Similar province controls for Canada include fraction in urban areas, fraction in the manufacturing sector, female, and average age. Data are grouped into means by birth year, region sex, race (for the U.S.), and survey year and weighted by population size. Huber-White standard errors are shown from clustering by region and birth cohort. Single, double, and triple asterix indicate significant coefficients at the 10 percent, 5 percent, and 1 percent levels respectively. See text for more data specifics. 
Table 3

OLS and IV Estimates of the Returns to Compulsory Schooling

for the U.S., Canada, and the U.K.

\begin{tabular}{|c|c|c|c|}
\hline & (1) & (2) & (3) \\
\hline & $\begin{array}{l}\text { OLS } \\
<\text { HS Sample }\end{array}$ & $\begin{array}{l}\text { IV } \\
\text { Full Samp. }\end{array}$ & $\begin{array}{c}\text { IV } \\
<\text { HS Sample }\end{array}$ \\
\hline Dependent Variable & \multicolumn{3}{|c|}{$\begin{array}{l}\text { United States [1901-61 Birth Cohorts aged 25-64 } \\
\text { in the } 1950-2000 \text { Censuses] }\end{array}$} \\
\hline \multirow[t]{2}{*}{ Log Weekly Earnings (all workers) } & 0.079 & 0.133 & 0.095 \\
\hline & {$[0.0005]^{\star * *}$} & {$[0.0118]^{\star \star *}$} & {$[0.0224]^{\star \star \star}$} \\
\hline \multirow[t]{2}{*}{ Log Weekly Earnings (males) } & 0.070 & 0.122 & 0.157 \\
\hline & {$[0.0004]^{\star * *}$} & {$[0.0141]^{\star \star *}$} & {$[0.0252]^{\star \star *}$} \\
\hline \multirow[t]{4}{*}{ Log Weekly Earnings (black males) } & 0.074 & 0.158 & 0.140 \\
\hline & {$[0.0004]^{* * *}$} & {$[0.0132]^{\star * *}$} & {$[0.0207]^{\star * *}$} \\
\hline & \multicolumn{3}{|c|}{ Canada [1911-61 Birth Cohorts aged 25-64 } \\
\hline & \multicolumn{3}{|c|}{ in the 1971-2001 Censuses] } \\
\hline \multirow[t]{2}{*}{ Log Annual Earnings (all workers) } & 0.088 & 0.084 & 0.132 \\
\hline & {$[0.0008]^{* * *}$} & {$[0.0103]^{* * *}$} & {$[0.0145]^{\star * *}$} \\
\hline \multirow[t]{4}{*}{ Log Annual Earnings (males) } & 0.107 & 0.106 & 0.138 \\
\hline & {$[0.0010]^{\star * *}$} & {$[0.0121]^{\star * *}$} & {$[0.0152]^{\star * \star}$} \\
\hline & \multirow{2}{*}{\multicolumn{3}{|c|}{$\begin{array}{l}\text { United Kingdom [1921-51 Birth Cohorts aged 32-64 } \\
\text { in the 1983 - } 1998 \text { GHHS] }\end{array}$}} \\
\hline & & & \\
\hline \multirow[t]{2}{*}{ Log Annual Earnings (all workers) } & 0.147 & 0.158 & 0.074 \\
\hline & {$[0.0058]^{\star \star *}$} & {$[0.0491]^{\star \star *}$} & {$[0.0420]^{*}$} \\
\hline \multirow[t]{2}{*}{ Log Annual Earnings (males) } & 0.134 & 0.094 & 0.073 \\
\hline & {$[0.0071]^{\star * *}$} & [0.0568] & {$[0.0516]$} \\
\hline
\end{tabular}

Notes: All regressions include fixed effects for birth year, region (state, province, Britain/N.Ireland), survey year, sex (for the full sample only), and a quartic in age. The U.S. results also include a dummy variable for race (except for the regression for black males) and state controls for fraction of state living in urban areas, fraction black, in the labor force, in the manufacturing sector, female, and average age based on when a birth cohort was age 14. Similar province controls for Canada include fraction in urban areas, fraction in the manufacturing sector, female, and average age. Data are grouped into means by birth year, nation, sex, race (for the U.S.) and survey year. Huber-White standard errors are shown from clustering by region and birth cohort. Single, double, and triple asterix indicate significant coefficients at the 10 percent, 5 percent, and 1 percent levels respectively. See text for more data specifics. 
Table 4

OLS and IV Estimates for Effects of Compulsory Schooling on Health and Other Social-Economic Outcomes

\begin{tabular}{|c|c|c|c|c|}
\hline & $\begin{array}{c}(1) \\
\text { Mean } \\
<\text { HS Sample }\end{array}$ & $\begin{array}{c}(2) \\
\text { OLS } \\
<\text { HS Sample }\end{array}$ & $\begin{array}{c}\text { (3) } \\
\text { IV } \\
\text { Full Sample }\end{array}$ & $\begin{array}{c}\text { (4) } \\
\text { IV } \\
<\text { HS Sampl }\end{array}$ \\
\hline Country (Schooling Variable) & \multicolumn{4}{|c|}{ Health Outcomes (ages 25 - 84) } \\
\hline \multicolumn{5}{|l|}{ United States (Total Years of Schooing) } \\
\hline $\begin{array}{l}\text { Physical or mental health } \\
\text { disability that limits personal care }\end{array}$ & 0.092 & $\begin{array}{c}-0.014 \\
{[0.0003]^{\star \star \star}}\end{array}$ & $\begin{array}{c}-0.025 \\
{[0.0058]^{\star \star \star}}\end{array}$ & $\begin{array}{c}-0.029 \\
{[0.0126]^{\star \star}}\end{array}$ \\
\hline Disability that limits mobility & 0.128 & $\begin{array}{c}-0.020 \\
{[0.0004]^{\star \star \star}}\end{array}$ & $\begin{array}{c}-0.043 \\
{[0.0070]^{\star \star \star}}\end{array}$ & $\begin{array}{c}-0.031 \\
{[0.0191]}\end{array}$ \\
\hline \multicolumn{5}{|c|}{ United Kingdom (Age Left Full Time Education) } \\
\hline Self Reported Poor Health & 0.150 & $\begin{array}{c}-0.037 \\
{[0.0016]^{\star * *}}\end{array}$ & $\begin{array}{c}-0.032 \\
{[0.0113]^{\star * *}}\end{array}$ & $\begin{array}{c}-0.019 \\
{[0.0085]^{\star \star}}\end{array}$ \\
\hline Self Reported Good Health & 0.564 & $\begin{array}{c}0.065 \\
{[0.0021]^{\star \star \star}}\end{array}$ & $\begin{array}{c}0.060 \\
{[0.0155]^{\star \star \star}}\end{array}$ & $\begin{array}{c}0.025 \\
{[0.0115]^{\star \star}}\end{array}$ \\
\hline
\end{tabular}

Other Social-Economic Outcomes (ages 25 - 64)

United States (Schooling Variable: Total Years of Schooing)

Unemployed

Receiving welfare

Below poverty line

\section{Canada (Highest Grade Attended)}

Unemployed; looking for work

Below low-income cut-off

\section{United Kingdom (Age Left Full Time Education)}

In labor force; looking for work

Receiving income support
0.064

0.067

0.220

0.062

0.227

0.110

0.066
-0.004
$[0.0002]^{\star \star *}$

-0.013
$[0.0002]^{\star \star \star}$

$-0.023$

$[0.0002]^{* * *}$

$-0.009$

$[0.0004]^{* * *}$

$-0.038$

$[0.0004]^{\star * *}$

$-0.030$

$[0.0044]^{\star * *}$

$-0.025$

$[0.0024]^{\star \star \star}$
$-0.005$

[0.0040]

$-0.011$

$[0.0024]^{\star * *}$

$-0.064$

$[0.0085]^{\star * *}$

$-0.010$

$[0.003]^{\star \star *}$

$-0.026$

$[0.0038]^{\star * \star}$

$-0.032$

$[0.0150]^{\star *}$

$-0.059$

$[0.0259]^{\star *}$
$-0.026$

$[0.0103]^{\star *}$

$-0.020$

$[0.0068]^{\star \star *}$

$-0.085$

$[0.0151]^{\star * *}$

$-0.013$

$[0.004]^{\star \star *}$

$-0.019$

$[0.0068]^{\star * *}$

$-0.020$

[0.0166]

$-0.031$ $[0.0150]^{\text {** }}$

Notes: All regressions include fixed effects for birth year, region (state, province, Britain/N.Ireland), survey year, sex, and a quartic in age. The U.S. results also include a dummy variable for race and state controls for fraction of state living in urban areas, fraction black, in the labor force, in the manufacturing sector, female, and average age based on when a birth cohort was age 14. Similar province controls for Canada include fraction in urban areas, fraction in the manufacturing sector, female, and average age. Data are grouped into means by birth year, nation, sex, race (for the U.S.) and survey year. Huber-White standard errors are shown from clustering by region and birth cohort. Single, double, and triple asterix indicate significant coefficients at the 10 percent, 5 percent, and 1 percent levels respectively. See text for more data specifics. 


\section{Table 5}

\section{Average Financial Gain from Dropping Out One Year Later,}

Measured in Present Value (2000 U.S. dollars)

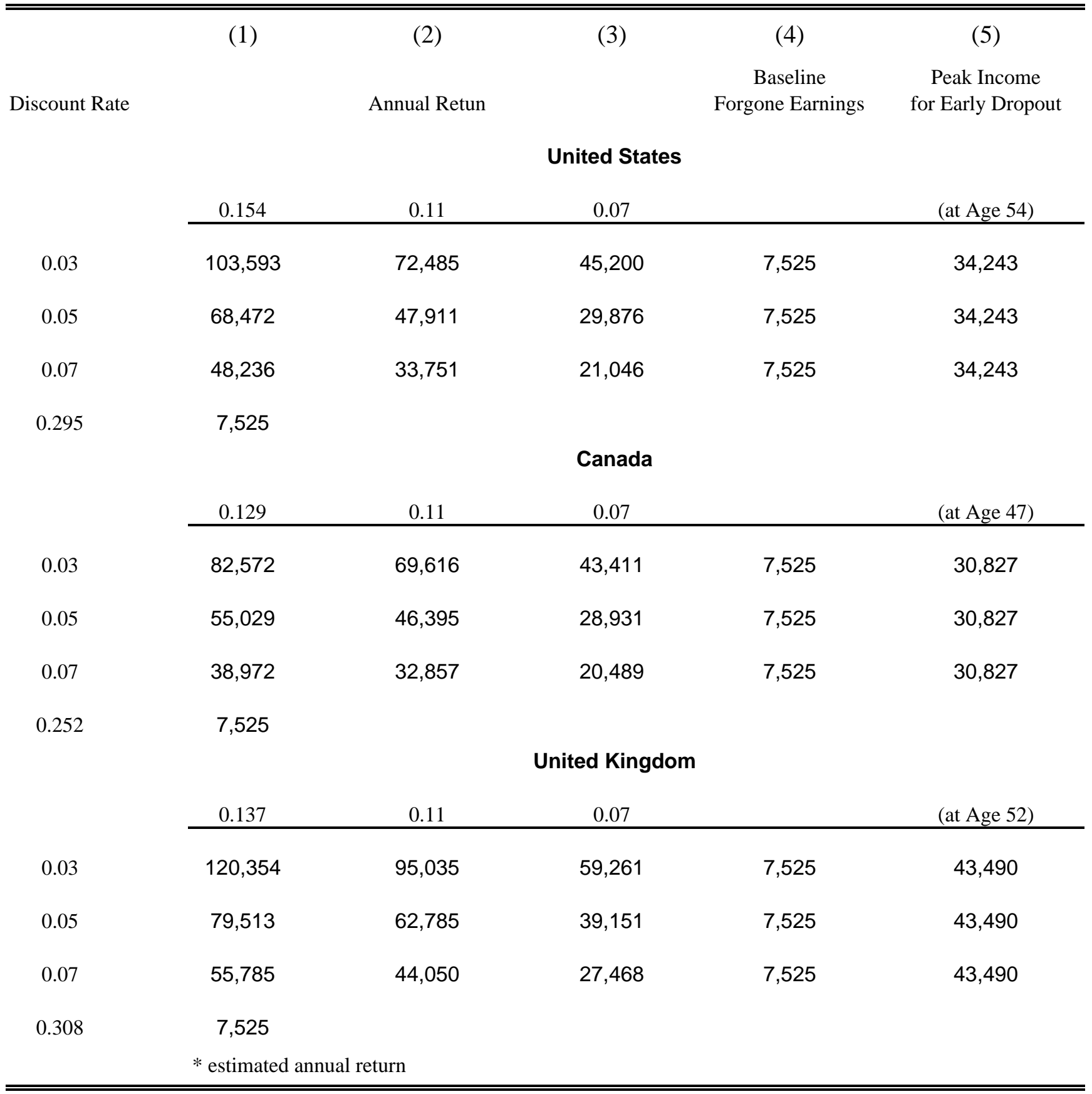

Notes: Projected wage profiles among 15 and 16 year-old dropouts between the ages of 16 and 64 are shown in Figure 5 . Column 1 shows the estimated annual returns to compulsory schooling from the instrumental variable regressions used to create these profiles. Column 1 also converts the annual profile differences to present value at age 15. Columns 2 and 3 show present value gains assuming alternative annual returns to compulsory schooling (.11 and .07 rspectively). The baseline wage for a 15 year old dropout at age 15 is $\$ 7,525$. The fourth row for each country shows the discount factor needed to generate present value gains equal to this amount. Column 5 displys the projected peak earnings for a 15 -yearold dropout. 